\section{ل̌⿱}

Investing in rural people
Papers of the 2019 Rural

Development Report

\title{
Climate and jobs for rural young people
}

by

Karen Brooks

Shahnila Dunston

Keith Wiebe

Channing Arndt

Faaiqa Hartley

Richard Robertson

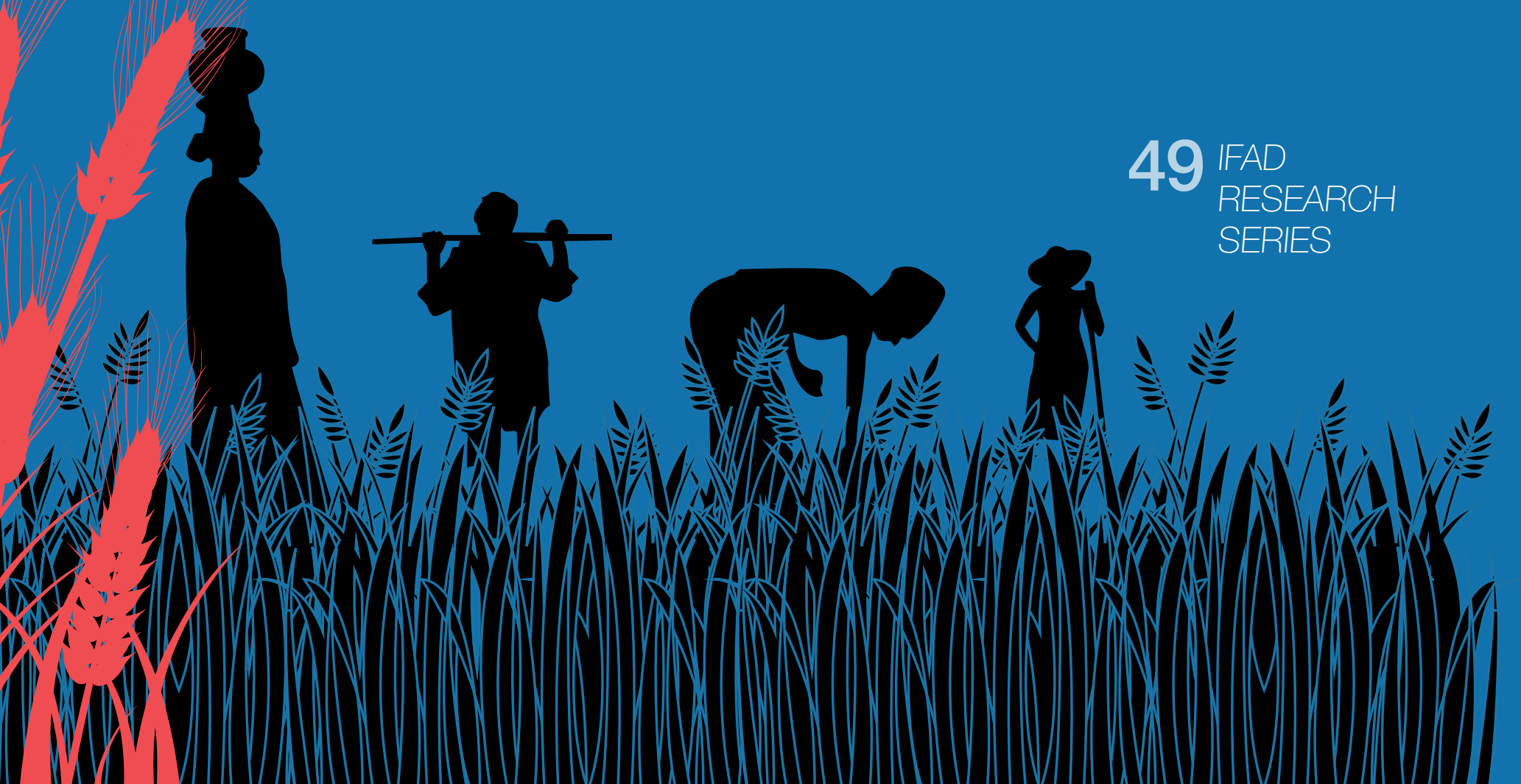


The IFAD Research Series has been initiated by the Strategy and Knowledge Department in order to bring together cutting-edge thinking and research on smallholder agriculture, rural development and related themes. As a global organization with an exclusive mandate to promote rural smallholder development, IFAD seeks to present diverse viewpoints from across the development arena in order to stimulate knowledge exchange, innovation, and commitment to investing in rural people.

The opinions expressed in this publication are those of the authors and do not necessarily represent those of the International Fund for Agricultural Development (IFAD). The designations employed and the presentation of material in this publication do not imply the expression of any opinion whatsoever on the part of IFAD concerning the legal status of any country, territory, city or area or of its authorities, or concerning the delimitation of its frontiers or boundaries. The designations "developed" and "developing" countries are intended for statistical convenience and do not necessarily express a judgement about the stage reached in the development process by a particular country or area.

This publication or any part thereof may be reproduced for non-commercial purposes without prior permission from IFAD, provided that the publication or extract therefrom reproduced is attributed to IFAD and the title of this publication is stated in any publication and that a copy thereof is sent to IFAD.

\section{Authors:}

Karen Brooks, Shahnila Dunston, Keith Wiebe, Channing Arndt, Faaiqa Hartley and Richard Robertson

(c) IFAD 2019

All rights reserved

ISBN 978-92-9072-966-2

Printed December 2019 


\section{幽 \\ JlIFAD}

Investing in rural people

\section{Climate and jobs for rural young people}

by

Karen Brooks

Shahnila Dunston

Keith Wiebe

Channing Arndt

Faaiqa Hartley

Richard Robertson 


\section{Acknowledgements}

The authors acknowledge support from IFAD and from the CGIAR Research Program on Policies, Institutions, and Markets. This paper draws on Brooks (2018), Rising absolutely, declining relatively: agriculture, climate change, and job creation in Africa, Agrekon, 57:3-4,181-197, with permission of the publisher.

This background paper was prepared for the Rural Development Report 2019 "Creating Opportunities for Rural Youth". Its publication in its original draft form is intended to stimulate broader discussion around the topics treated in the report itself. The views and opinions expressed in this paper are those of the author(s) and should not be attributed to IFAD, its Member States or their representatives to its Executive Board. IFAD does not guarantee the accuracy of the data included in this work. For further information, please contact ruraldevelopmenreport@ifad.org. IFAD would like to acknowledge the generous financial support provided by the Governments of Italy and Germany for the development of the background papers of the 2019 Rural Development Report.

\section{About the authors}

Karen Brooks is Adjunct Professor, Georgetown University. She was previously Director of the CGIAR Research Program on Policies, Institutions, and Markets led by the International Food Policy Research Institute (IFPRI); and Sector Manager, Agricultural Operations, the Africa Region of the World Bank. While at the World Bank she also worked in Europe and Central Asia on policy issues of the transition during the 1990s. Prior to joining the World Bank she was Associate Professor in the Department of Applied Economics at the University of Minnesota. She received both her master's degree and $\mathrm{PhD}$ in economics from the University of Chicago.(International Food Policy Research Institute (IFPRI), https://orcid.org/0000-00022016-5844).

Shahnila Dunston is a Senior Research Analyst at the International Food Policy Research Institute in Washington, D.C. She received her BA in economics from Hanover College and MS in agricultural economics from the University of Illinois at Urbana-Champaign. Her current work focuses on scenario analysis of the agricultural sector using IFPRI's International Model for Policy Analysis of Agricultural Commodities and Trade (IMPACT). (Environment and Production Technology Division, IFPRI, https://orcid.org/0000-0002-3589-3350; email: s.dunston@cgiar.org.

Keith Wiebe is a Senior Research Fellow at IFPRI in Washington, D.C., where he leads a research programme on Global Futures and Strategic Foresight in partnership with the 15 international agricultural research centres of the CGIAR. Previously he was with the United Nations Food and Agriculture Organization in Rome and the US Department of Agriculture's Economic Research Service in Washington, D.C. He received his BA in economics from Carleton College, and his MA and $\mathrm{PhD}$ in agricultural economics from the University of Wisconsin-Madison. (Environment and Production Technology Division, IFPRI, https://orcid.org/0000-0001-6035-620X).

Channing Arndt has more than 25 years of experience in development economics with seven years combined resident experience in Morocco and Mozambique. He has published more than 70 articles in leading academic journals. His recent books include Growth and Poverty in sub-Saharan Africa; Measuring Poverty and Wellbeing in Developing Countries; and The Political Economy of Clean Energy Transitions. He has substantial research management 
experience, including leadership of interdisciplinary teams, and has taken leadership roles in major policy documents such as the design of a carbon tax for the National Treasury of South Africa, the Economics of Adaptation to Climate Change study for the World Bank, and the Second, Third and Fourth National Poverty Assessments for the Government of Mozambique. He has an established reputation for effectively building institutional capacity in Mozambique, South Africa, Morocco, Viet Nam and within the framework of the African Economic Research Consortium. His programme of research has focused on agricultural development, poverty alleviation and growth, market integration, gender and discrimination, the implications of the HIV/AIDS pandemic, technological change, trade policy, aid effectiveness, infrastructure investment, energy, bioenergy, climate variability and the implications of climate change. (Environment and Production Technology Division, IFPRI, https://orcid.org/0000-0003-24726300).

Faaiqa Hartley is a senior researcher in the Energy Systems, Economics, and Policy group at the Energy Research Centre, University of Cape Town. She holds an MCom in econometrics from the University of Pretoria and a BBusSci in economics and management from the University of Cape Town. She is an economist whose research has centred on developmental issues in Africa, primarily South Africa. She has 10 years of experience in policy development and analysis, and is proficient in economy-wide modelling techniques including computable general equilibrium (CGE) models. Her current research areas include the use of CGE models to understand and quantify the economic trade-offs and implications of energy, waste and climate change policies in South Africa and sub-Saharan Africa. (University of Pretoria, https://orcid.org/0000-0001-9799-3923).

Richard Robertson is a research fellow at the International Food Policy Research Institute. His work revolves primarily around the implications of climate change on crop productivity and land use at the global scale in explicitly spatial contexts. He often employs crop simulation modelling in support of economic models at scales ranging from global all the way down to the farm level. (Environment and Production Technology Division, IFPRI, https://orcid.org/00000001-5741-3867). 


\section{Table of contents}

1. Introduction 1

2. How will climate change affect employment prospects and the general economy? 1

3. Geography of youth populations and global climate change 4

4. How important is agriculture likely to be as an employer of young people, and where? 5

$\begin{array}{ll}\text { 5. How will climate change affect agriculture? } & 6\end{array}$

6. Is adaptation feasible for agriculturally dependent countries with youthful populations? 9

7. Equipping young people with skills to manage the uncertainties of climate change $\quad 10$

8. A policy and institutional agenda for climate resilient jobs for rural young people 11

9. Conclusions 13

$\begin{array}{ll}\text { Tables and figures } & 14\end{array}$

$\begin{array}{ll}\text { References } & 27\end{array}$ 


\section{Abstract}

Climate change matters for all young people. It matters especially for those whose livelihoods depend on agriculture and will continue to do so in the future due to slowing growth in labour-intensive manufacturing and constraints on labour absorption in the service sector. Of the slightly more than 500 million rural young people projected globally in 2030, two thirds will be in sub-Saharan Africa and in South Asia. In many African countries farming still employs over half of a rapidly growing labour force, and the absolute number of agricultural workers is still rising (although the share of the labour force is falling with structural transformation). Where agriculture is called upon to deliver job security as well as food security, vulnerability to climate change presents major risks for the large numbers of young job-seekers. Adaptation to climate change is feasible, and options will increase as new technologies and management approaches come onstream. Adaptation requires proactive planning and investments in relevant infrastructure and agricultural science. Strategies for job creation in highly affected countries must accord more attention than is the case at present to agriculture, both on the farm and in the food system. 


\section{Introduction}

For many young people in the world's fastest growing countries, agriculture must contribute to job security as much as food security. In these countries especially, climate change and youth employment are interlinked.

Much of the narrative addressing climate change and agriculture focuses on the challenge of feeding a world of 9.8 billion people in 2050 with crops, livestock and farmers ill equipped for an altered agroecology. The concern is largely framed around global agriculture, global food security and global climate change, although impacts are localized and regionally specific (Guldberg et al., 2018). Countries highly dependent on agriculture for livelihoods will be among those that suffer significant yield loss due to changes in temperature, precipitation and the frequency of adverse weather events. In many, large cohorts of young people are joining the labour force in primary agriculture and related activities. Agricultural adaptation globally that produces sufficient food for the world's people will not address the needs of these young agricultural workers if their local agricultural systems lose competitiveness under the new conditions. Their farms and agrifood systems will have to become more productive under conditions even more challenging than today's.

\section{How will climate change affect employment prospects and the general economy?}

Agriculture and activities drawing on natural resources are among the sectors most affected by climate change. Yet the precise ways in which climate change will influence opportunities are uncertain and therefore hard to predict. General circulation models show a wide range of climate futures. Uncertainty tends to grow as geography narrows, and local effects can be projected only with wide confidence intervals.

General equilibrium models can be very helpful for exploring how climate change reverberates through an economy and triggers adjustments. In general, the aggregate predicted effects of changes expected in 2050 in a fully adjusted economy are surprisingly modest, even when more severe scenarios of climate change are modelled. For example, Arndt and Thurlow (2015) identify four channels through which climate change affects economic prospects in Mozambique: agriculture, roads, hydropower and cyclonic sea level surges. In each case a probability distribution of likely outcomes incorporating climate change relative to a baseline of no climate change is developed for a horizon to 2050. Agriculture experiences a loss of yield. The road network contracts (compared to the projection without climate change) due to high costs of repair after repeated flooding and temperature spikes. Generation of hydropower falls with reduced flow of the major rivers. The higher sea level exacerbates saline incursion of storm surges. Partially offsetting these negative impacts is a lower world oil price assumed to result from shifts to renewable energy in the high-income countries. Mozambique, as a relatively intensive user of imported energy per unit of GDP, would benefit from lower global oil prices.

In the model developed by Arndt and Thurlow, the aggregate and most probable impact of climate change on GDP in 2050 is relatively modest, at about 5 per cent loss relative to the baseline with no climate change. The impacts are distributed unevenly across rural and urban areas. Rural areas will feel the brunt of agriculture's yield loss and the deteriorating road system, while urban areas will be more affected by reduction in hydropower and storm surges in coastal cities. The timing and distribution of impacts are hard to predict, since some are relatively steady (for example, yield deterioration), and others result from extreme events (for example, coastal flooding and drought). 
Cullis et al. (2015) consider the impact of 367 potential climate futures for South Africa using an integrated modelling approach in which the impact of changes in climate on crop yield, water supply and demand, and road infrastructure is considered. Their findings show a negative but relatively modest aggregate impact of climate change on economic growth over the next 10-20 years. National averages mask a high degree of heterogeneity at the local level. The subnational impacts are large and highly variable across climate futures, particularly for agriculture.

Research by UNU-WIDER (2012) assesses the impacts of climate change on the economy of Viet Nam on crop yields, irrigation water availability, hydropower production, road infrastructure, sea level rise and cyclone strikes. The study uses a structural modelling approach that links several biophysical models to a dynamic national computable general equilibrium model. The results show that the combined impact in 2046-2050 of all climate channels considered is negative but modest: between -0.5 per cent and -3.0 per cent of GDP over the 56 climate futures considered.

The general equilibrium models offer optimism that the changes ahead need not be catastrophic if appropriate adjustment is facilitated and if more affected locales are assisted by less affected ones. The general equilibrium models may, however, underestimate the impact on particular subgroups of the population, such as rural young people seeking to construct livelihoods on farms. Partial equilibrium models can be helpful for clarifying the nature of sectoral shocks and adjustments in agriculture.

The modelling work undertaken by IFPRI and the CGIAR Global Futures and Strategic Foresight (GFSF) programme - a partial equilibrium framework - projects that global food prices will rise with climate change. Recent price movements have tempered some of the concerns about rising prices voiced after the price spikes of 2008-2009 and 2011-2012, but the data and assumptions underlying the GFSF work show prices displayed in table $1 .{ }^{1}$ Real cereal prices are projected to rise somewhat in 2030 and 2050 relative to 2010 prices even without climate change. Adding in the effects of climate change without compensatory adaptation (that is, with price response but no adjustment in technology) roughly doubles the relative price increase for cereals.

The higher prices can be seen in light of the FAO (2018) food price index illustrated in figure 1, which shows a rising trend since about 2000, despite the dip since the peak of 2012. Much of the analysis that follows draws on the assumptions embodied in the GFSF modelling effort and is consistent with the projection of rising prices.

A projected change in the real price of food has implications for job creation, poverty reduction and structural transformation. Swinnen and Squicciarini (2012) point out that higher food prices create gainers as well as losers. Net sellers of food products gain, but gains can be offset through other impacts of higher prices. Higher food prices can slow job creation in labour-intensive manufacturing and services as competitiveness erodes relative to alternative suppliers. Higher food prices mean that real consumption shrinks as consumers divert budgets to pay for food. Many poor smallholder farmers are net buyers of food, particularly in lean months, and what they gain from higher prices of marketed output they lose in higher prices of purchased food.

\footnotetext{
${ }^{1}$ IMPACT is a partial equilibrium multimarket global model of production, trade, demand and prices for all major agricultural commodities. The core multimarket model also links to various other models (crop, water, malnutrition) and thus can be thought of as a linked system of models. The "core" multimarket model equates demand and supply of commodities across the globe and provides values for production, demand and prices. Areas and yields of commodities are determined by exogenous factors (such as climate shocks, water shocks, productivity growth and price in input factors) as well as the endogenous price effect. There is also a trade-off between commodities in planting area based on their relative prices as solved by the model. Climate change is modelled as yield shocks through a linkage with crop models (DSSAT). More detailed information can be found in the documentation (Robinson et al., 2015a).
} 
Poor countries with rapidly growing populations are in many cases net importers of food. Climate change projections show increased imports; for example, in West Africa, as growth in demand outstrips climate-affected supply (Wiebe et al., 2017). Unless exports of non-agricultural products are growing as food imports rise, exchange rate effects will compound the increase in global food prices for domestic consumers. The constellation of economy-wide effects of climate change through slower growth, shifts in trade balances and real exchange rates, and reduced competitiveness for tradable goods and services will slow job creation overall and impede opportunities for young people entering the labour market.

Higher food prices shift resources toward agricultural production, including young people who farm. Countries with good agricultural resources and ample agricultural labour that invest enough in agriculture to capture growing markets can benefit from higher prices associated with climate change, and partially offset negative impacts. A sectoral shift toward agriculture occasioned by price effects of climate change can be expected to bring slower aggregate growth (because of the composite effects of climate change) but more abundant jobs in agriculture and related activities (since agriculture is labour-intensive). Just as the commodity boom of the early 2000 s is associated with "jobless growth," that is growth that boosted GDP but raised employment little, climate change could bring its mirror image, "job creating slow growth," in countries that invest in adaptation of agriculture.

Climate change is just one among many factors that influence the structural evolution of economies. Even abstracting from climate change, evidence suggests that the process of structural transformation in the twenty-first century is quite different from that of the past. Recent work by McMillan et al. (2017) and Diao et al. (2017) looks in detail at the relative contributions of within-sector productivity growth and cross-sectoral shifts of labour as contributors to observed growth in selected countries. Although their work does not explicitly address climate change and focuses on the recent past (since 1990 or later), their findings are relevant for our inquiry.

If demand for labour in services and manufacturing is high, many young people with requisite skills will be able to exit agriculture and move up a productivity gradient by securing jobs with higher pay in services and manufacturing. If demand for labour in manufacturing and services is constrained, exit from agriculture will be more difficult and less rewarding. The ability to attract labour-intensive manufacturing and sell into global markets will depend on the pace of substitution of capital for labour through automation globally, as well as the given country's investment climate, real wages, infrastructure and the skill level of the labour force - the factors that McMillan et al. (2017) identify as "fundamentals." Similarly, growth of labour productivity in the service sector will depend on domestic demand for services and prospects for expansion of traded services, such as tourism and finance.

Countries with diversified economies (that is, a small share of agriculture relative to services and manufactures) and solid fundamentals (that is, good indicators of human capital and infrastructure) will in general be able to offer young rural people a range of occupational choices. Those that have large youth cohorts, low levels of diversification and poor fundamentals will offer fewer choices outside farming and directly related occupations. McMillan et al. (2017) present a landscape of slowing structural transformation, particularly where fundamentals are weak. Young people in these places are likely to face a quadruple burden of poverty, climate change, delayed demographic transition and slow structural change. Their exit from farms for other occupations will be slower than during transformations in the past, and their opportunities will depend significantly on the performance of agriculture. 


\section{Geography of youth populations and global climate change}

Figure 2 shows the time trend of the youth population by region up to $2100{ }^{2}$ African leaders concerned about job prospects for cohorts of about 200 million young people now will have 275 million to plan for each year in 2030 and an estimated 400 million in 2050 (shown as sub-Saharan Africa [SSA] in figure 2). The much larger economies in South Asia (shown as part of Asia and the Pacific Region [APR]) will need to absorb a larger but more slowly growing cohort that will peak in about 2035. East Asia's rapidly ageing population raises a different set of issues. The other regions (Latin America and the Caribbean [LAC], and Near East, North Africa and Europe [NEN]), which have largely completed the demographic transition, will, according to these projections, have more stable numbers of young people.

Occupational choice and sectoral destination of young people entering the labour force will depend in part on whether they reside in urban or rural areas. An assumption that the cohorts of young people mirror the projected national trajectories of urbanization yields figure 3 . This assumption is probably wrong in two ways that counterbalance each other. Rural families are larger than urban, and so more young people will be born in the countryside. However, people in the age range 15-24 are more likely to migrate from rural areas to cities than is the population at large. Given these two countervailing factors, the assumption that the 15-24-year-old cohort follows the general projections of urbanization is reasonable.

Rural cohorts in Africa south of the Sahara will be larger than the urban ones until about 2040. In South Asia (subsumed within the aggregate for APR in figure 3) the cohorts will be equal in size in about 2040, after which the urban group will dominate. By mid-century, therefore, when the impact of climate change on agriculture is accelerating, in both Africa south of the Sahara and South Asia employment of rural young people will be of national and not just local significance.

Figure 4 shows a scatter plot of countries pairing projected increase in heat stress (a common proxy for climate change, where extreme heat includes both temperature and humidity - see Robertson, 2016) in 2050 with the proportion of young people in the population. The change in heat stress measures more than simply whether a country is tropical or not. For example, Rwanda, Burundi and Uganda have warm climates as measured by the historical data, but not many extreme heat days. With the climate scenario projected to 2050, each of these countries registers a large increase in extreme heat days. In contrast, Somalia has a historic record of many extreme days; since the number was high in the base period, the increase is smaller. Countries in the upper right quadrant will have both increased heat stress and a proportionately large cohort of young people in 2050.

Two clusters of dots stand out. The cluster in the lower left quadrant shows that most countries likely to experience little increased heat stress have ageing populations. The cluster in the upper right shows that many countries with high youth populations (more than 15 per cent in the 15-24 age range) will be hard hit. Most of the upper right quadrant countries are in Africa south of the Sahara, although Haiti is also included. Southeast Asian countries also experience high heat stress, and their proportion of

\footnotetext{
${ }^{2}$ Data displayed are from the United Nations median variant. Most modelling efforts, including the CGIAR GFSF work, use the Intergovernmental Panel on Climate Change (IPCC) AR5 Shared Socioeconomic Pathways (SSP) to model income growth and population. The IPCC AR5 demographic assumptions differ from those of the United Nations, with the difference widening in outer years. The IPCC population projection for SSP2 for 2030 is 8.2 billion, while the United Nations number is 8.5 billion. By 2100 different assumptions about growth in the outer years lead to a projection under SSP2 of 9.4 billion, compared to the United Nations median variant projection of 11.1 billion. The SSP projections are used for consistency with other modelling efforts, and to facilitate inter-model comparison. Data displayed in figures 4, 5 and 6 are from the IPCC data, since they draw on the IMPACT model.
} 
youth population is in many cases close to the 15 per cent line. The relatively empty lower right quadrant shows that very few countries with high youth populations will be spared the higher temperatures.

\section{How important is agriculture likely to be as an employer of young people, and where?}

Many of the countries with high youth populations and high vulnerability to heat stress are also dependent on agriculture. Figure 5 shows the array of countries by share of agriculture in GDP in 2016 and the projected proportion of young people in the population in 2030. A significant cluster of countries with relatively youthful populations in 2030 have advanced sufficiently in structural transformation that agriculture in 2016 contributed 20 per cent or less of the economy. A smaller but still significant group of countries with high projected youth populations in 2030 were moderately (20-30 per cent of GDP) or highly (greater than 30 per cent of GDP) dependent on agriculture in 2016. Because of low labour productivity in agriculture, the sector's share of employment is often at least twice its share of GDP; one can safely assume that countries in which agriculture constitutes 25 per cent or more of GDP will have half or more of the labour force employed in agriculture.

Tables 2 and 3 list two groups of countries shown in figure 5: those with high projected youth populations in 2030 also highly dependent on agriculture (Table 2), and those with high youth populations and more diversified economies (Table 3 ). The absolute numbers of young people in the agriculturally dependent countries with high youth populations (about 200 million) is greater than that in countries with more diversified economies, but even the countries classified as farther along in structural transformation (as shown in table 3) are relatively dependent on agriculture. Most of the countries highly dependent on agriculture are in Africa south of the Sahara, but the list also includes Nepal, Cambodia, Myanmar and Pakistan.

Figure 5 shows that countries with high projected youth populations in 2030 are relatively agricultural now. Will they remain so in the future? Or will structural transformation proceed quickly enough to open job opportunities in services or manufacturing for young people born on farms? Contributors to the McMillan et al. (2017) volume offer insights into the recent experience of structural transformation. They trace the evolution of labour productivity since 1990 in seven countries, tracking how much and under what circumstances aggregate growth can be attributed to increased productivity within sectors, and how much to a shift of labour from less productive sectors (usually agriculture) to more (services and manufacturing). Several generalizations relevant to our thinking about climate change and youth employment emerge from this work. Although it is often the case that a flow of labour from agriculture and services into manufacturing is growth-enhancing, this is not always the case. A comparison of two Indian states shows absorption of labour into agriculture with simultaneous rapid growth of productivity in Gujarat, compared to slower growth in service-heavy Maharashtra (Ahsan and Mitra, 2016). Ahsan and Mitra argue that a labour-absorbing transformation was accomplished in Gujarat through investments in infrastructure, agricultural science and education, water management, and policy changes that improved access to land and markets.

The flow of labour into agriculture in Gujarat is not anomalous, although it is somewhat out of synchrony with the stage of structural transformation more generally in India. In the early phase of transformation, agriculture absorbs more labour than it sheds. China's agricultural labour force peaked in about 1990, a decade after institutional reforms triggered acceleration in agricultural output and productivity that initiated structural transformation and growth in other sectors (Yeboah and Jayne, 2018). China's period of absolute increase and relative decline (that is, a rise in absolute numbers but decline in agriculture's share of the labour force) was shortened by population policy that brought down birth rates, but it nonetheless lasted for a decade. India's agricultural labour force peaked in 
2005 (KPMG and FICCI, 2015). India experienced decades of absolute rise and relative decline in the agricultural labour force while structural transformation proceeded apace. Viet Nam's agricultural labour force grew absolutely until a levelling during 2009-2014, after which it began to decline (General Statistics Office, 2017). The period of Viet Nam's absolute increase and relative decline of the agricultural labour force coincided with rapid growth in agricultural productivity and concurrent expansion of services and labour-intensive manufacturing. Although agriculture's share of the labour force in most African countries is falling - in some rapidly and in others more slowly - the absolute numbers of people employed are rising. Yeboah and Jayne (2018), working with the Groningen Growth and Development Centre Africa Sector Database, find that numbers of people and full-time equivalent units employed in African agriculture are rising, although with some variation across countries (Yeboah and Jayne, 2018).

That Africa's agricultural labour force is rising absolutely while the share declines is therefore not anomalous. Quite the opposite - an absolute net flow of labour out of agriculture would be extraordinary given the size of the agricultural labour force relative to the receiving sectors of services, construction, manufacturing and mining. Even as these sectors grow and absorb labour, they are not yet large enough to support a net reduction in the agricultural labour force, particularly with the prevailing persistent high birth rates. The period of absolute increase and relative decline in Africa's agricultural labour force is likely to be prolonged by the slow demographic transition.

The idea that many young people are finding jobs in agriculture defies predictions of massive exit based on attitudinal surveys. Queries about occupational choice administered to young people in poor countries routinely find that farming is listed among the less favoured occupations, although not always the least (Filmer and Fox, 2014). Yeboah and Jayne (2018) find that the average age of farmers in Africa is holding steady or falling, consistent with entry of the young. The evidence that agriculture in countries with rapid population growth is employing young people now and will continue to do so in the future augments the importance of climate change and of adaptation to it. Job prospects of young people will depend importantly on prospects for agriculture.

\section{How will climate change affect agriculture?}

The GFSF modelling group of CGIAR, led by IFPRI and involving participation of all CGIAR Centers and several external partners, has estimated the agricultural impacts of climate change under varying assumptions (see, for example, Islam et al., 2016; Robinson et al., 2015b; Rosegrant et al., 2017). The modelling framework is partial equilibrium, and draws on the International Model for Policy Analysis of Agricultural Commodities and Trade (IMPACT) economic and social model, Decision Support System for Agrotechnology Transfer (DSSAT) crop models, and modules capturing water availability and climate change. The models can be used to construct plausible scenarios of demand, supply, prices, trade, risk of hunger, nutrition and environmental stress at levels of geographic disaggregation from global to regional conditions. The results reported here assume moderate economic growth (Shared Socioeconomic Pathway 2, or SSP2) and rapid climate change (Representative Concentration Pathway 8.5, or RCP8.5). Agricultural productivity is assumed to grow at roughly the levels observed in recent years in both the baseline (no climate change) and the climate change scenario, but in the latter a yield shock is superimposed on the productivity path. The implications of these assumptions for agricultural revenue at the national level in 2030 and 2050 are shown in figures 6 and 7.

Change in revenue is comprised of change in yield (in the crop and livestock sectors) and change in price. Figures 6 and 7 show that for most countries in 2030 and in 2050, the projected increase in global prices more than compensates for the yield loss, and gross farm revenue with climate change exceeds the baseline without climate change. For a few countries in 2030 and more in 2050, the yield loss dominates, and revenue is depressed. 
Countries with high youth populations fall into both categories (revenue gains and revenue losses), although more experience gains. Clearly, the few countries that experience yield loss with insufficient countervailing price gain lose significantly from climate change. The somewhat surprising finding that many countries will experience revenue gains does not suggest that climate change is good for these countries. As noted above in the discussions of general equilibrium analysis of climate impact, higher food prices dampen growth and slow job creation in services and manufacturing. Yet as was seen in the price spikes of 2008-2009 and 2011-2012, higher relative prices for food shift economic activity toward agriculture and favour domestic production over imports. Higher real food prices will increase the relative importance of agriculture compared to the no climate change baseline and raise the flow of labour and capital into agriculture relative to the no climate change scenario.

A comparison of the agricultural impacts of climate change in the LAC and SSA regions, as derived from the GFSF models, is shown in box 1 . The impacts of climate change in LAC equal or in some cases exceed those estimated in SSA. As shown in tables 2 and 3 , however, none of the countries in LAC is highly dependent on agriculture while also being delayed in the demographic transition. Young people in LAC are fewer in numbers and will have more options for other employment as climate change affects farming than is the case in SSA, although localized effects may be severe.

The revenue gains shown in figures 6 and 7 can be enhanced if agricultural productivity in countries with high youth populations grows faster than the modelling exercise assumes; that is, if technical change facilitates rapid adaptation and recovery of yield loss. In that case the two right quadrants would shift upward. Since few of the major global agricultural producers are in the set of countries with high youth populations, production within this group could increase substantially without affecting global prices (and hence depressing revenues).

Figures 6 and 7 illustrate risks as well as opportunities. A first risk relates to the distribution of benefits associated with potentially higher real prices and successful adaptation to climate change. If returns to resources employed in agriculture rise, will young people gain or lose? They are likely to gain as agricultural labourers, as prices rise and production expands. The experience of 2008/2009 and subsequently confirms that land values rise with agricultural prices. Young people who wish to farm are often at a disadvantage in accessing land, particularly in settings where land rights and transactions are ambiguous. A successful adaptation to climate change with job creation for young people will require attention to land administration and proactive programmes to facilitate access of young adults (aged 25-34) to land for farming. Ricker-Gilbert and Chamberlin (2018) find that more active rental markets benefit people in the young adult age range (25-34) but have little bearing on opportunities for the younger group. They also find that young adults face higher rents and higher transactions costs associated with rental contracts than do older people. 
Box 1. Climate change and agriculture in LAC: high impact, but fewer young people are affected

Agriculture in LAC countries is also affected by climate change. Guatemala, Dominican Republic and Haiti all have sizeable youth populations, but only Haiti is still agricultural (at around 20 per cent of GDP). The table below shows the impacts in 2050 on area, yield and production for major crops in LAC compared to SSA, as estimated by the GFSF modelling work using the IMPACT model. market actors elsewhere.

\begin{tabular}{|c|c|c|c|c|c|}
\hline & & $\begin{array}{l}\text { No climate } \\
\text { change }\end{array}$ & \multicolumn{3}{|c|}{$\begin{array}{l}\text { Percent change due to climate change in } \\
2050\end{array}$} \\
\hline Region & Crop Group & $\begin{array}{l}\text { Cultivated } \\
\text { area in } 2050\end{array}$ & $\begin{array}{l}\text { Cultivated } \\
\text { area }\end{array}$ & Production & Yield \\
\hline LAC & Cereals & 56,421 & $1.50 \%$ & $-11.50 \%$ & $-13.00 \%$ \\
\hline SSA & Cereals & 109.723 & $2.40 \%$ & $-6.00 \%$ & $-8.20 \%$ \\
\hline LAC & $\begin{array}{l}\text { Coffee, Tea, } \\
\text { etc. }\end{array}$ & 13,016 & $-2.90 \%$ & $-11.50 \%$ & $-9.10 \%$ \\
\hline SSA & $\begin{array}{l}\text { Coffee, Tea, } \\
\text { etc. }\end{array}$ & 24,043 & $-1.10 \%$ & $-8.70 \%$ & $-7.20 \%$ \\
\hline LAC & $\begin{array}{l}\text { Fruits and } \\
\text { Vegetables }\end{array}$ & 8,390 & $-2.10 \%$ & $-9.90 \%$ & $-8.00 \%$ \\
\hline SSA & $\begin{array}{l}\text { Fruits and } \\
\text { Vegetables }\end{array}$ & 20,612 & $-1.40 \%$ & $-11.90 \%$ & $-10.70 \%$ \\
\hline LAC & Oilseeds & 61,539 & $5.80 \%$ & $-4.60 \%$ & $-9.80 \%$ \\
\hline SSA & Oilseeds & 27,458 & $6.90 \%$ & $-7.50 \%$ & $-13.50 \%$ \\
\hline LAC & Pulses & 10,064 & $-4.50 \%$ & $-9.50 \%$ & $-5.30 \%$ \\
\hline SSA & Pulses & 26,299 & $0.90 \%$ & $-4.10 \%$ & $-4.90 \%$ \\
\hline LAC & $\begin{array}{l}\text { Roots and } \\
\text { tubers }\end{array}$ & 4,361 & $1.40 \%$ & $-2.30 \%$ & $-3.60 \%$ \\
\hline SSA & $\begin{array}{l}\text { Roots and } \\
\text { tubers }\end{array}$ & 29,624 & $-1.40 \%$ & $-8.40 \%$ & $-7.10 \%$ \\
\hline LAC & Sugar Crop & 12,087 & $12.30 \%$ & $-3.10 \%$ & $-13.70 \%$ \\
\hline SSA & Sugar Crops & 977 & $9.90 \%$ & $1.10 \%$ & $-8.10 \%$ \\
\hline
\end{tabular}

For all crops in both regions, production falls. Shifts in area between and among crops and changes in aggregate area cultivated determine the impact on production. For some commodities (cereals, sugar), the yield reductions in LAC exceed those in SSA. Although the overall impact on rural young people in LAC will be less than in Africa and South Asia, localized effects can be severe. For example, rural Andean communities are already affected by changes in temperature and hydrology.

A second risk relates to differential pace of productivity change. If productivity growth in poor and young countries lags rates observed recently, then yield loss will be higher and more countries will fall into the territory of negative revenues. Moreover, high-income temperate countries, most of which are in the lower left quadrant offigure 5, may adapt faster than the model predicts, and recover their own yield loss. These countries are large and will have impacts on global trade and prices. In such a case global prices would rise little if at all, and producers in low-income, less-dynamic countries would experience yield loss without commensurate price gains. The distribution of dots in figures 6 and 7 would shift downward, with many more of the countries with high youth populations falling into the territory of revenue loss. Failure to adapt carries high risks, especially for young people, and adds urgency to the focus on investment to assure competitiveness. 


\section{Is adaptation feasible for agriculturally dependent countries with youthful populations?}

Potentially climate-resilient technologies are already known and partially adopted, and others are under development. Although models are at present unable to provide specific advice for given localities, they can provide insight into the implications of generalized adoption of currently known technologies. Table 4 shows estimated price effects in 2050 of seven potentially climate-smart technologies in cereal crops compared to a baseline of nonadaptation. Comparing tables 1 and 4 leads to the conclusion that rapid adoption of these potentially climate-smart technologies for the cereals would lessen the projected price increase in 2050 by about one half, depending on the mix of technologies, but would not remove it.

Recent collaborative work undertaken by four CGIAR Centers (IFPRI, the International Crops Research Institute for the Semi-Arid Tropics, the International Maize and Wheat Improvement Center, and the International Potato Center) evaluated the potential of heat and drought tolerant technologies. New technologies for maize, wheat, potatoes, sorghum and groundnuts were modelled using the DSSAT family of crop models (Hoogenboom et al., 2012; Jones et al., 2003) to obtain biophysical information on how these technologies affect yields. The yield shocks were then used as inputs to the IMPACT model to simulate the effects of the new varieties under no climate change and climate change scenarios.

In these studies, the technologies were assumed to be widely adopted in countries where CGIAR scientists saw potential benefits from the new varieties based on soil and climate characteristics. More information about the specific assumptions made regarding adoption and other parameters in these studies can be found in Robinson et al. (2015b) and Islam et al. (2016).

In figure 8, the zero line represents projected yields without climate change. The new technologies for specific crops are in some cases able to counteract the decline in yields associated with climate change; in other words, the technologies are adaptive to the new agroecology. In others (for example, rainfed sorghum in Africa and India) prospects are bleak even under the adaptive technologies tested here. In the figure both exogenous and endogenous yield effects are shown. The exogenous effects come from the crop model and are purely biophysical (climate change and adoption of new technologies), whereas the endogenous results incorporate market effects that model how farmers respond to changes in prices. In most cases the market effects dampen the exogenous yieldenhancing impacts, as farmers observe the local price adjustments to higher supply on markets.

Even with the market effects, the adoption of the technology can offset the impact of climate change in the region of adoption; for example, rainfed maize in Africa has 20 per cent higher yields under the adaptive technologies (Islam et al., 2016; Robinson et al., 2015b). Further, regions that adopt the new technologies improve their trade positions, reducing imports or adding to exports. The lower dependence on imports reduces vulnerability to global price shocks (Robinson et al., 2015b).

Four technologies show potential applicability in a number of settings: no-till and integrated soil fertility management in maize and wheat production, alternate wetting and drying in rice, and urea deep placement in rice. New work being done by IFPRI uses the IMPACT system of models to explore how adoption of these potentially climate-smart technologies in locations where they are well suited may affect production, prices, food security, and greenhouse gas emissions globally and in SSA to 2050 (De Pinto et al., 2017). The authors find that adoption can increase production of those three crops in SSA by up to 50 per cent by 2050 relative to a baseline scenario. Area harvested and two measures of food insecurity (population at risk of hunger and number of undernourished children) are projected to decline, while reductions in greenhouse gas emissions depend on choices of the farmers in their adoption decisions. 
A recent analysis by Rosegrant et al. (2017) in collaboration with colleagues in the 15 CGIAR Centers examined three sets of alternative scenarios of investment in agricultural research, water management and marketing infrastructure as part of a strategy to address climate change. A fourth comprehensive scenario combines elements from the first three.

Within each of the four basic scenarios, different portfolios of investment were examined. The baseline, or reference scenario, included three alternatives: significant climate change (RCP 8.5 as modelled under two different systems) and one with no climate change. The scenarios for productivity enhancement explored five options: medium levels of investment in CGIAR, high levels of investment in CGIAR, high investment in CGIAR plus increased investment in national partners, high investment in CGIAR plus increased efficiency in achieving impacts of research, and specific targeting of CGIAR research toward Africa south of the Sahara and South Asia. Each of these scenarios brings faster growth in total factor productivity than the baselines. A third set of scenarios addresses improved water management, with corresponding increased investments to achieve it. A fourth set examines returns to investments in infrastructure. A fifth combines the four scenarios to examine additional returns that come from synergies among them. The scenarios are described in summary in table 5.

The alternative investment scenarios vary widely in their costs. Table 6 summarizes key impacts of ten scenarios for objectives covering growth and food supply, hunger, environmental indicators and greenhouse gas emissions. Changes in agricultural employment will be most closely correlated with the indicators of change in GDP and agricultural supply. The investments in agricultural research under the various configurations increase GDP and agricultural supply at intermediate cost. In contrast, investments in water management and irrigation, when undertaken separately from those in agricultural research, are high cost and bring little change in agricultural competitiveness, as seen in GDP and agricultural supply. Major campaigns to expand infrastructure and irrigation would presumably create jobs in the construction sector, but the impact of these investments will be limited unless combined with investments in improved agricultural technology. The package that delivers the largest boost to agricultural supply and GDP (and presumably employment) is the comprehensive package, with concurrent investment in agricultural research, infrastructure and water management. Such an investment programme would have the advantage of improving the competitiveness of agriculture and simultaneously increasing demand for labour in construction of rural infrastructure.

\section{Equipping young people with skills to manage the uncertainties of climate change}

Even the best programme of public investment in agricultural research and rural infrastructure will carry little benefit for rural young people if they lack skills to guide complex decision-making in the new environment. Young people well prepared to cope with climate change will need skills to manage uncertainty, and especially competence and confidence to gather information and respond flexibly. With school enrolments rising worldwide, successive generations of young people are better educated than their parents, and even than brothers and sisters. In much of the developing and middle-income world, school completion for young people is now the norm rather than the exception. Educational transition matrices calculated for South Africa and Viet Nam, for example, show that almost all young people enter primary school at ages 6 or 7 , and most remain in school through grades 9 or 10 (IFAD, 2016). Murtin (2013) and Uys and Alant (2015) find that progression rates in primary school education in South Africa (grades 1-7) are relatively high at 90 per cent or more, and these decrease in secondary schooling (grades 8-12) as more students repeat grades and exit the system. In Viet Nam grade transitions estimated from administrative data for 2000-2006 show that over 97 per cent of pupils progress from primary school (grades 1-5) to lower secondary school (grades 6-9), and 94 per 
cent eventually graduate from upper secondary school (grades 1012 ) (General Statistics Office, 2015).

Figure 9 shows that despite high rates of school attainment, over half of young people in South Africa are unemployed, due to a combination of structural features of the South African economy and poor quality in the classroom. Education and supply side interventions more generally to increase skills of young people will not produce jobs without concurrent attention to the demand for labour.

Figure 10 shows that South Africa's educational attainment differs greatly from data for the rest of Africa south of the Sahara. Despite recent improvements in school enrolment, only about 25 per cent of the young people working in agriculture have completed primary school; 40 per cent have either not attended school or not completed the primary grades. Moreover, those who remain in school through the primary grades often do not attain basic literacy and numeracy.

Since the school systems in much of Africa have been so far unable to provide the needed skills, innovative programmes of extension, peer learning and use of public media will be needed to help rural young people manage adaptation to climate change. Educational reform in rural areas is a core element of adaptation to climate change.

\section{A policy and institutional agenda for climate resilient jobs for rural young people}

Adaptation is feasible, as argued above, and if pursued vigorously can underpin a labour-absorbing agricultural transformation. The growth in labour productivity and earnings as farms and related activities draw in additional labour will be less steep than was the case in East Asia earlier. Economies such as Viet Nam with strong fundamentals in education and infrastructure and expansion of labourintensive manufactures provided job opportunities in non-agricultural enterprises, as well as on farms, thereby benefiting from a double impetus to productivity growth. Countries less far along in the transformation are likely now to experience a flatter trajectory of productivity growth. It can nonetheless be positively sloped if investments and policy reforms are supportive.

More years and higher quality of schooling will provide the generalized skills to process information and make decisions under changing and uncertain conditions. After mastery of basic skills, emphasis on "learning how to learn" will be as or more important than standardized curricula emphasizing vocational and technical training in agriculture.

The ability to manage fertility is empowering for young people, especially women and girls, and it affects the path of growth in labour productivity. Large families put more strain on agriculture to absorb labour and thereby exert downward pressure on availability of land and on labour productivity. Between 1960 and 2016 the fertility rate in Uganda declined from 7.0 to 5.6, while in Viet Nam it fell from 6.3 to 2.0 (World Bank, 2017; General Statistics Office, 2015).

The investments in roads and telecommunications that connect rural areas to towns and cities make young people more content to remain in rural areas, and more productive when they do. Connectivity is particularly important for the information flows about how climate is changing, new price projections, implications for agricultural management practices, and just-in-time advice and mentoring for adoption of new and more resilient technologies and management practices. Investments in roads and telecommunications complement an array of new approaches to provision of advisory services, such as ICT-mediated extension programmes and use of volunteer farmer trainers backed up by professional extension staff. Improved communications expand the options with which rural young people can manage information flows to support their economic activities. 
Beyond the generalized investments in rural education, reproductive health, roads and telecommunications are those specific to climate resilient agricultural transformation. Most of the countries that will need to create job opportunities for young people in agriculture are at present underinvesting in agricultural science. Figure 11 shows investment in agricultural science as a proportion of agricultural GDP arrayed against the age distribution of the population. The young countries most in need of dynamic agriculture to create jobs invest proportionately less in agricultural science. This is particularly the case for Africa south of the Sahara; the data do not show subnational figures for India. The research intensities shown in figure 11 are a very crude measure of the adequacy of research effort, and more nuanced measures are under development (see Nin-Pratt, 2016).

Institutional and organizational reforms to increase the efficiency of and returns to agricultural research should accompany the increased investment. Among the needed measures are stronger linkage between and among national, regional and international research organizations, with specialization and sharing of research results. Large national systems, such as the Indian Council of Agricultural Research, have advantages in this regard over small fragmented national systems. The latter can be joined into regional research complexes, as for example has begun with subregional coordination of research in Africa, but much more is needed to overcome past deficiencies in funding and organization that persist to this day (Wiebe et al., 2017).

Investments in agricultural infrastructure and science must be targeted to intended purposes. Because of the multifunctional nature of agriculture, investments can respond to varying objectives, including inter alia agricultural growth, nutrition, land management and ecology, climate resilience and job creation. In different regions of the world, specific motivations will lead to different portfolios of investment. Where rural youth populations are large and growing and climate change likely to have a large impact, investments should be tailored to focus on adaptation and job creation. This may require some difficult choices and deviation from traditional agricultural investments. Analytical tools can help to identify commodities and technologies in which investment will boost climate resilience and job creation, and in this way assist in shaping an investment portfolio (Thurlow et al., 2018).

In addition to an appropriately dimensioned and configured portfolio of agricultural investment, special measures will be needed to increase inclusion of young people. These will address access to land, information and finance, and will vary according to context. Clarification of inheritance rights to land and easing of restrictions on rental are particularly important for young people. Increased transparency when land passes from customary tenure to private freehold would provide young people with more opportunities to participate in such transactions. Programmes can be designed that combine transfer of land, start-up grants, and mentorship to qualified promising young farmers in the age range of young adults (25 34). Traditional extension programmes are not likely to suit the informational needs of young people, but alternative approaches relying on social networks (such as volunteer farmer trainers) and ICT-based extension show promise in recent evaluations. The financing needs of young farmers are best met through grants in the early years, after which they will have enough experience to use standard financial instruments. 


\section{Conclusions}

Climate change matters to all rural young people everywhere and especially to young people whose livelihoods will depend on agriculture. The largest concentrations of young people entering farming and related activities in the years ahead will be in regions with delayed demographic transition (and hence many young people) and delayed structural transformation (and hence large agricultural sectors). For these young people successful agricultural adaptation to climate change is imperative. Adaptation requires foresight and a willingness on the part of national and international leaders to

invest not only in the education and health of young people, but also in the sector that will be their major employer. Resources will need to flow into agricultural science and rural infrastructure on a scale greater than is taking place now.

Without such investment, the countries and regions that will employ millions of rural young people in 2030 and 2050 will face unmitigated downside risk as climate change intensifies. Their agricultural competitiveness will erode as wealthier and more diversified economies adapt faster and encroach on local and regional food markets. Young people will survey their options and take their talents where they can pursue opportunities denied them at home; their exit will undercut the promise of a youth dividend for themselves and their countries. The alternative of investing now to create jobs in agriculture for today's and tomorrow's young people is preferred, feasible and urgent. 


\section{Tables and figures}

Table 1. Price projections from the IMPACT model in 2030 and 2050 with and without climate change (values are indexed to 2010 value)

\begin{tabular}{|l|c|c|c|c|}
\hline & \multicolumn{2}{|c|}{ No climate change } & \multicolumn{2}{c|}{ With climate change } \\
\hline & 2030 & 2050 & 2030 & 2050 \\
\hline Cereals & 1.11 & 1.20 & 1.25 & 1.55 \\
\hline Dairy & 1.13 & 1.10 & 1.14 & 1.12 \\
\hline Fruits and vegetables & 1.16 & 1.32 & 1.25 & 1.51 \\
\hline Meats & 1.26 & 1.22 & 1.29 & 1.27 \\
\hline Oilseeds & 1.14 & 1.17 & 1.31 & 1.52 \\
\hline Pulses & 1.12 & 1.13 & 1.20 & 1.29 \\
\hline Roots and tubers & 1.14 & 1.25 & 1.27 & 1.51 \\
\hline Stimulants and other & 1.19 & 1.25 & 1.30 & 1.44 \\
\hline Sugar & 1.24 & 1.33 & 1.29 & 1.19 \\
\hline Vegetable meals & 1.09 & 1.16 & 1.17 & 1.10 \\
\hline Vegetable oils & 1.15 & & & \\
\hline
\end{tabular}

Source: Rosegrant et al. (2017). 
Table 2. Countries with agricultural share of GDP above 25 per cent and corresponding youth share of population in 2030 (total youth population for these countries is projected at 201 million)

\begin{tabular}{|c|c|c|}
\hline Country & $\begin{array}{c}\text { Percentage of the } \\
\text { population 15-24 in } 2030\end{array}$ & $\begin{array}{l}\text { Percentage of GDP in } \\
\text { agriculture } 2016\end{array}$ \\
\hline Sierra Leone (SLE) & 21 & 59 \\
\hline Chad (TCD) & 21 & 50 \\
\hline Guinea-Bissau (GNB) & 20 & 49 \\
\hline Central African Republic (CAF) & 21 & 43 \\
\hline Mali (MLI) & 21 & 42 \\
\hline Guyana (GSA) & 16 & 41 \\
\hline Togo (TGO) & 20 & 41 \\
\hline Burundi (BDI) & 20 & 40 \\
\hline Sudan (SDN) & 20 & 39 \\
\hline Ethiopia (ETH) & 20 & 37 \\
\hline Kenya (KEN) & 20 & 36 \\
\hline Liberia (LBR) & 20 & 34 \\
\hline Nepal (NPL) & 17 & 33 \\
\hline United Republic of Tanzania (TZA) & 20 & 32 \\
\hline Rwanda (RWA) & 20 & 32 \\
\hline Burkina Faso (BFA) & 21 & 31 \\
\hline Malawi (MWI) & 21 & 28 \\
\hline Mauritania (MRT) & 19 & 27 \\
\hline Cambodia (KHM) & 18 & 27 \\
\hline Uganda (UGA) & 21 & 26 \\
\hline Benin (BEN) & 20 & 26 \\
\hline Myanmar (MMR) & 16 & 25 \\
\hline Mozambique (MOZ) & 20 & 25 \\
\hline Madagascar (MDG) & 19 & 25 \\
\hline Pakistan (PAK) & 19 & 25 \\
\hline
\end{tabular}

Source: Authors based on data from World Bank, 2017 
Table 3. Countries with youth share of population over 19 per cent and agricultural share of GDP below 25 per cent (total youth population for these countries is 153 million)

\begin{tabular}{|c|c|c|}
\hline Country & $\begin{array}{c}\text { Percentage of the } \\
\text { population 15-24 in } 2030\end{array}$ & $\begin{array}{l}\text { Percentage of GDP in } \\
\text { agriculture } 2016 \\
\text { Percentage of GDP in } \\
\text { agriculture }\end{array}$ \\
\hline Afghanistan (AFG) & 21 & 22 \\
\hline Zimbabwe (ZWE) & 21 & 11 \\
\hline Gambia (The) (GMB) & 21 & 18 \\
\hline Senegal (SEN) & 20 & 17 \\
\hline Democratic Republic of the Congo (COD) & 20 & 22 \\
\hline Mozambique (MOZ) & 20 & 25 \\
\hline Cameroon (CMR) & 20 & 17 \\
\hline Congo (COG) & 20 & 9 \\
\hline Nigeria (NGA) & 20 & 21 \\
\hline Zambia (ZMB) & 20 & 7 \\
\hline Yemen (YEM) & 20 & 10 \\
\hline Eswatini (SWZ) & 20 & 10 \\
\hline Guinea (GIN) & 20 & 20 \\
\hline Côte d'Ivoire (CIV) & 20 & 23 \\
\hline Ghana (GHA) & 20 & 20 \\
\hline Lesotho (LSO) & 20 & 6 \\
\hline Madagascar (MDG) & 19 & 25 \\
\hline Equatorial Guinea (GNQ) & 19 & 3 \\
\hline Namibia (NAM) & 19 & 7 \\
\hline
\end{tabular}

Source: Authors based on data from World Bank, 2017 
Table 4. Per cent change in world price for maize, rice and wheat compared to baseline without adoption of improved technologies in 2050

\begin{tabular}{|c|c|c|c|c|c|c|}
\hline & \multicolumn{2}{|c|}{ Maize } & \multicolumn{2}{|c|}{ Rice } & \multicolumn{2}{|c|}{ Wheat } \\
\hline & CSIROA1E & MIROC A1B & CSIROA1B & MIROC ATE & CSIROATE & MIROC AIE \\
\hline Enhanced nitrogen-use efficiency & -11.14 & -12.04 & -20.43 & -20.33 & -8.22 & -8.39 \\
\hline No-till & -15.16 & -15.46 & -2.71 & -2.72 & -14.21 & -14.76 \\
\hline Precision agriculture & -3.75 & -4.88 & -10.54 & -10.32 & -10.63 & -9.74 \\
\hline Heat tolerance & -7.81 & -15.45 & -3.64 & -5.83 & -5.37 & -9.68 \\
\hline Integrated soil fertility management & -1.81 & .2 .44 & -7.84 & $-7,77$ & -4.33 & $-4,44$ \\
\hline Drought tolerance & -1.34 & -1.24 & -0.47 & -0.44 & -1.49 & -1.45 \\
\hline Water harvesting & -0.68 & -0.52 & .0 .07 & -0.06 & -0.18 & .0 .18 \\
\hline
\end{tabular}

Note: CSIRO A1B: drier and cooler climate compared to suite of IPCC AR4 SRES scenarios including MIROC A1B; MIROC A1B: wetter and warmer climate compared to suite of IPCC AR4 SRES scenarios including CSIRO A1B.

Source: IMPACT simulations in Rosegrant et al. (2017).

Table 5. The reference and alternative investment scenarios

\begin{tabular}{|c|c|c|}
\hline $\begin{array}{l}\text { Scenario } \\
\text { Grouping }\end{array}$ & Scenario & Scenario Description \\
\hline \multirow{3}{*}{ Reference } & REF_HGEM & $\begin{array}{l}\text { Reference scenario with RCP } 8.5 \text { future climate using HadGEM } \\
\text { GCM }\end{array}$ \\
\hline & REF_IPSL & Alternative reference with RCP 8.5 future climate using IPSL GCM \\
\hline & REF_NoCC & Alternate reference with no climate change (constant 2005 climate) \\
\hline \multirow{5}{*}{$\begin{array}{l}\text { Productivity } \\
\text { Enhancement }\end{array}$} & 1. (MED) & Medium increase in R\&D investment across the CGIAR portfolio \\
\hline & 2. (HIGH) & High increase in R\&D investment across the CGIAR portfolio \\
\hline & $\begin{array}{l}\text { 3. (HIGH+ } \\
\text { NARS) }\end{array}$ & $\begin{array}{l}\text { High increase in R\&D investment across the CGIAR portfolio plus } \\
\text { complementary national agricultural research system investments }\end{array}$ \\
\hline & 4. (HIGH+RE) & $\begin{array}{l}\text { High increase in R\&D investment across the CGIAR portfolio plus } \\
\text { increased research efficiency }\end{array}$ \\
\hline & 5. (REGION) & $\begin{array}{l}\text { Regionally-focused high increase in CGIAR R\&D investments; } \\
\text { targets the highest increases to South Asia and SSA with medium } \\
\text { levels of increase in Latin America and East Asia }\end{array}$ \\
\hline \multirow{3}{*}{$\begin{array}{l}\text { Improved Water } \\
\text { Resource } \\
\text { Management }\end{array}$} & 6. (IX) & Investments to expand irrigation in the developing world \\
\hline & 7. (IX+WUE) & Irrigation expansion plus increased water use efficiency \\
\hline & 8. (ISW) & Investments to increase soil water holding capacity \\
\hline $\begin{array}{l}\text { Improved } \\
\text { Infrastructure }\end{array}$ & 9. (RMM) & $\begin{array}{l}\text { Infrastructure improvements to improve market efficiency through } \\
\text { the reduction of transportation costs and marketing margins }\end{array}$ \\
\hline $\begin{array}{l}\text { Comprehensive } \\
\text { Investment }\end{array}$ & 10. (COMP) & $\begin{array}{l}\text { This comprehensive scenario is a combination of four scenarios: } \\
\text { 4. (HIGH+RE), 7. (IX+WUE), 8. (ISW) and 9. (RMM) }\end{array}$ \\
\hline
\end{tabular}

Source: Rosegrant et al. (2017). 
Table 6. Scenario impacts on selected outcome indicators in 2030 and 2050. Average annual costs are in billion US\$ per year for the developing world; all other values are percentage differences relative to the reference scenario (RCP 8.5 future climate using HadGEM GCM).

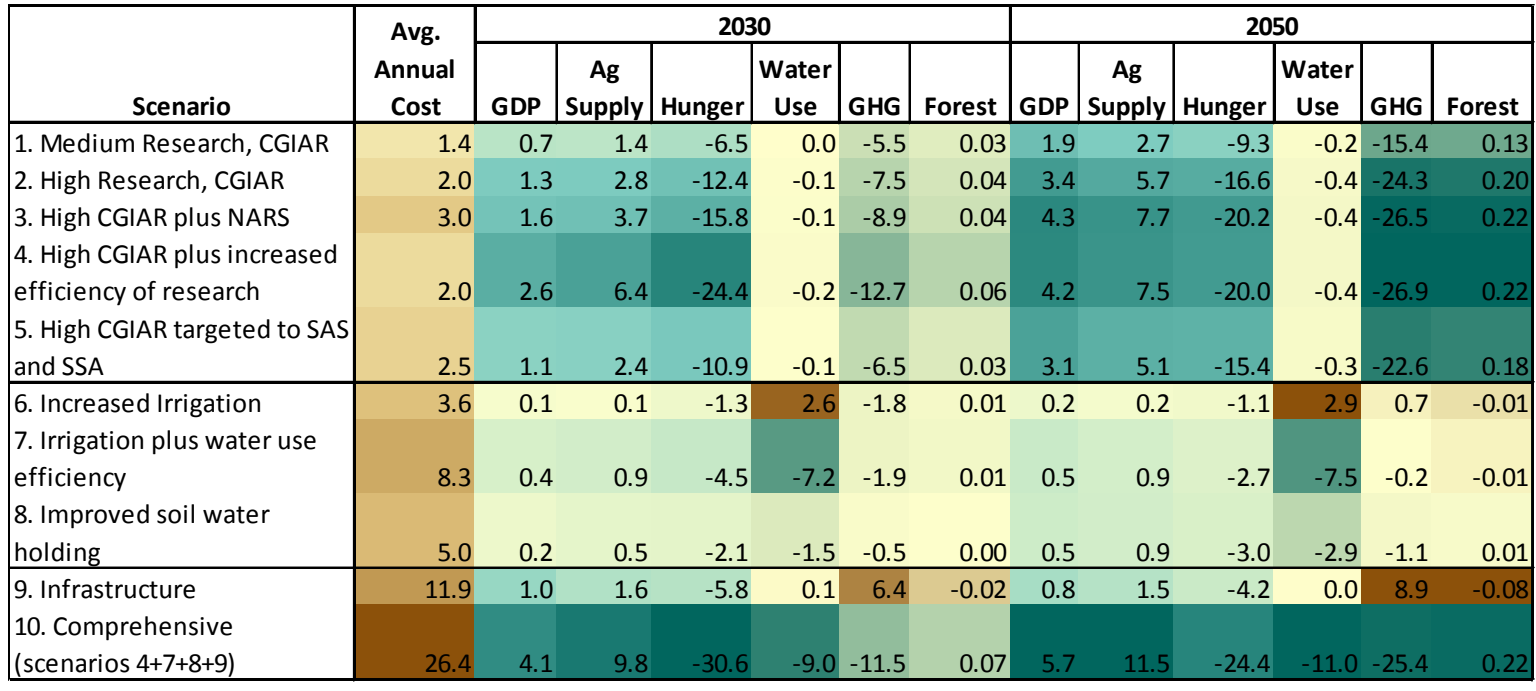

Notes: Ag Supply = agricultural supply; GHG = greenhouse gas; NARS = national agricultural research systems.

Source: Rosegrant et al. (2017). 
Figure 1. Trends in deflated food prices, 1970-2016

\section{FAO-Real Price Index}

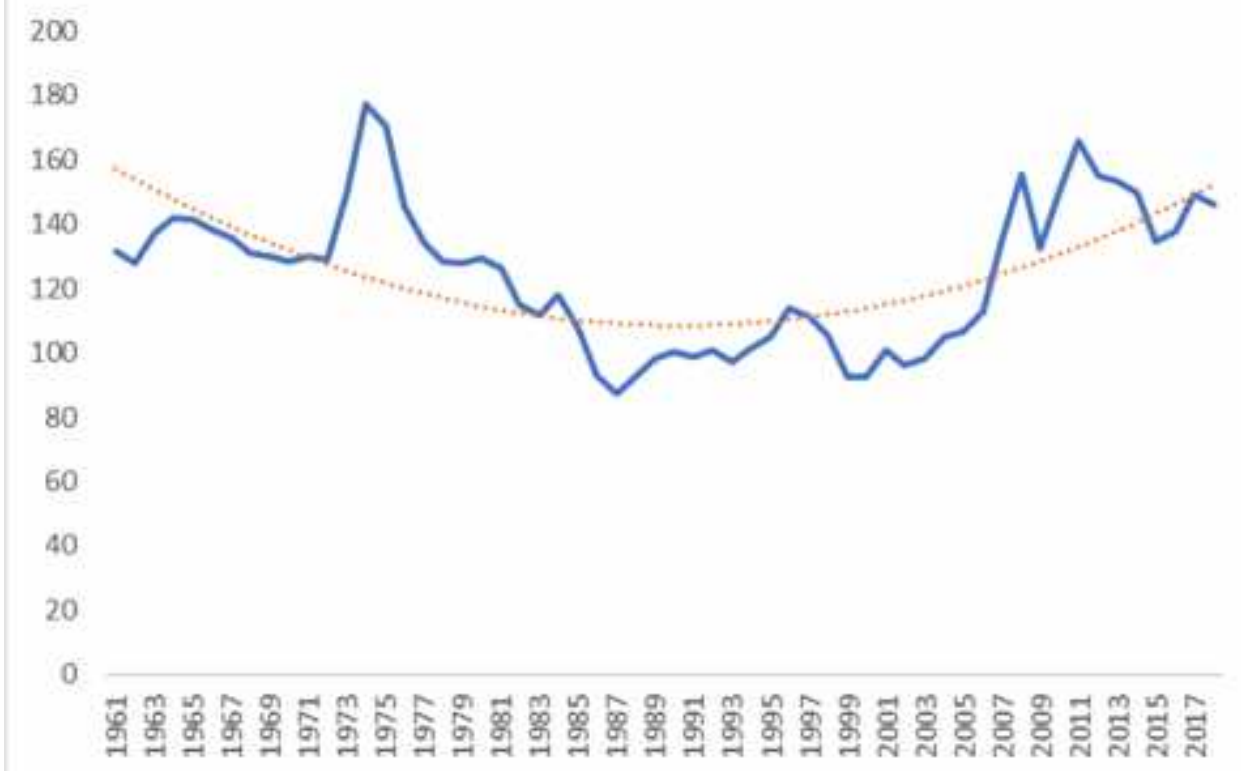

Source. Authors, based on data from FAO, 2018

Figure 2. Projected population of young people (15-24) by region (in millions, United Nations median variant, regions aggregated to show IFAD classification)

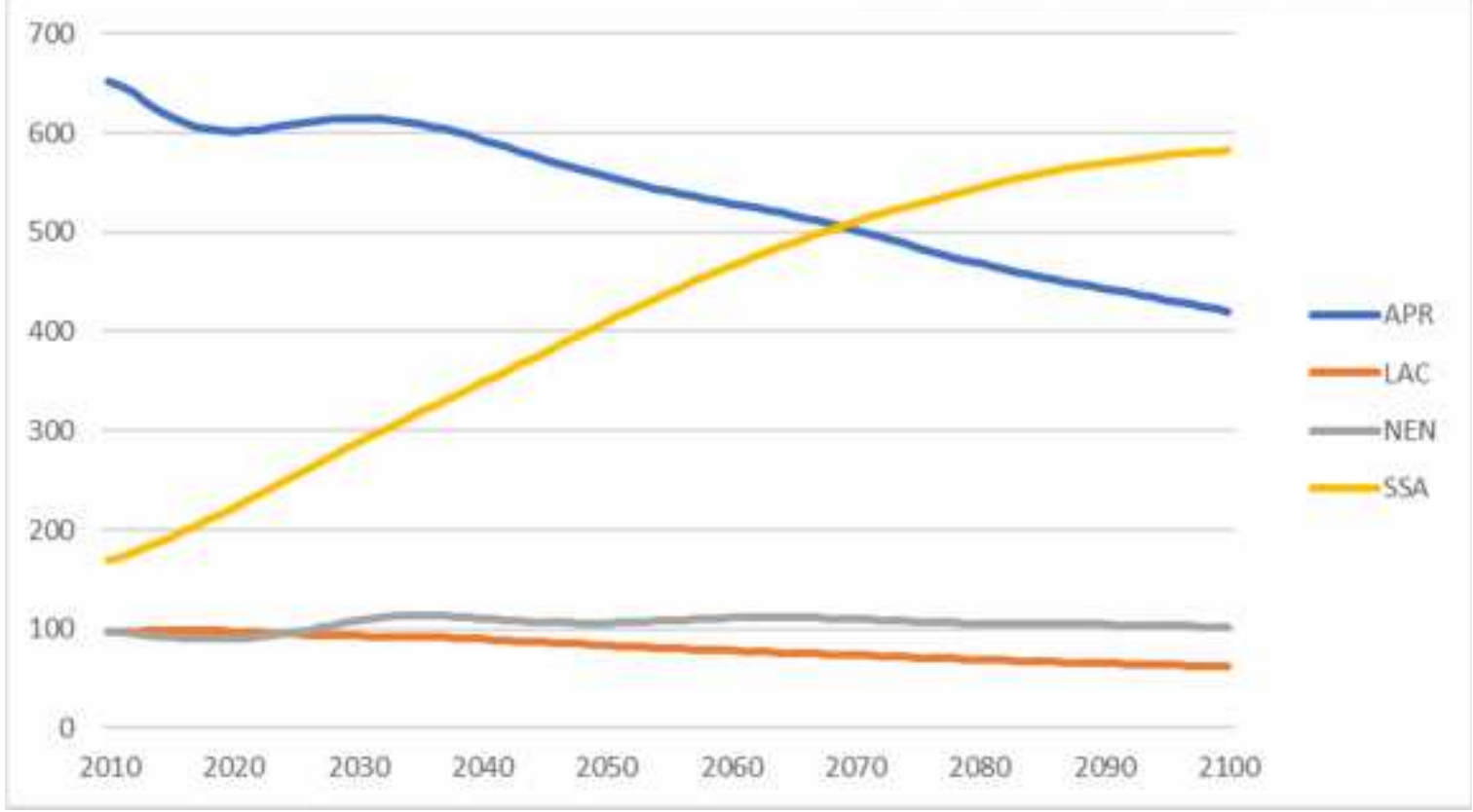

Source: Authors, based on data from UNDESA (2017). 
Figure 3. Non-urban young population (15-24) over time by region (in millions, United Nations median variant, regions aggregated according to IFAD classification)

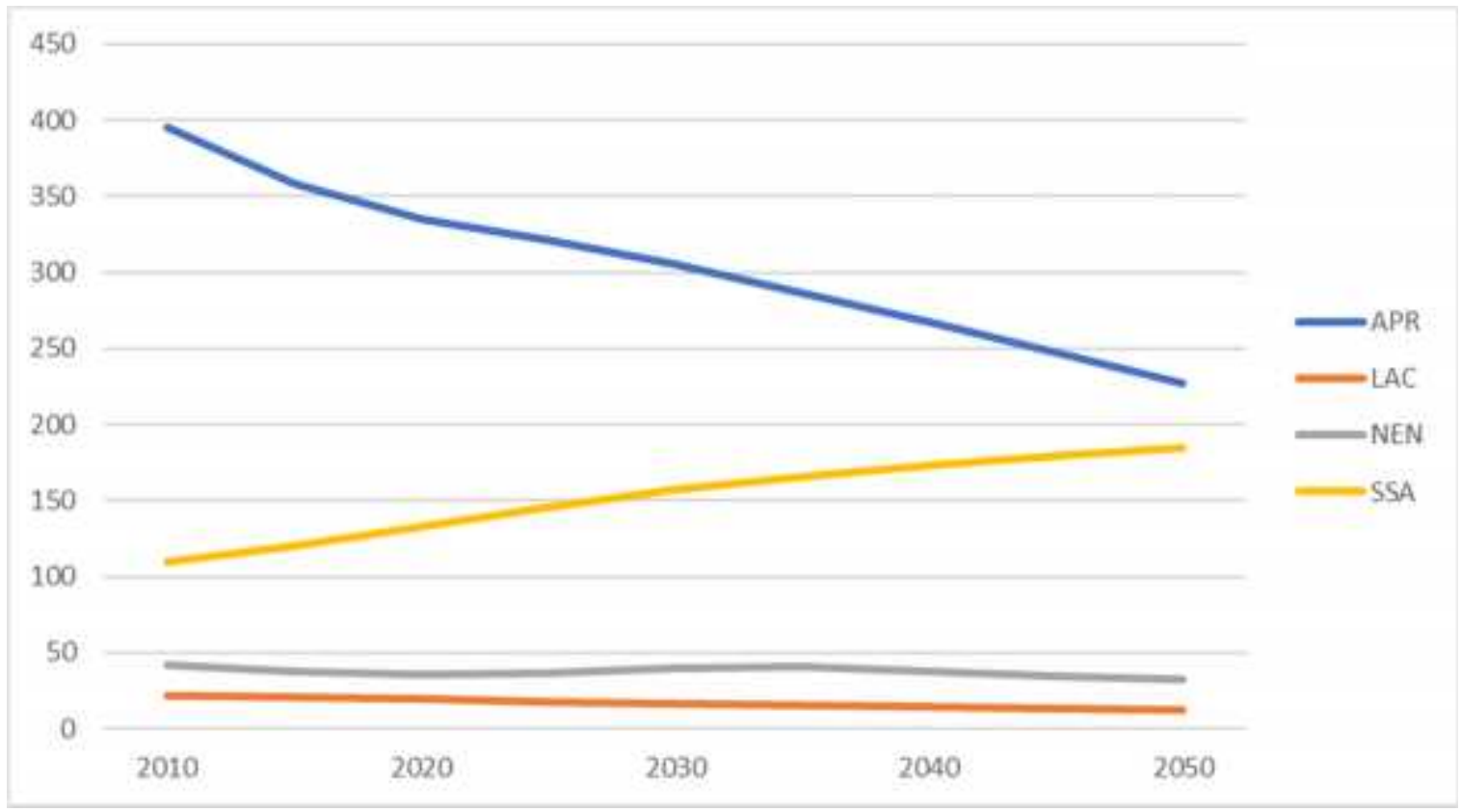

Source: Authors, based on data from UNDESA (2017). 
Figure 4. Proportion of youthful population and additional extreme heat days by country, 2050

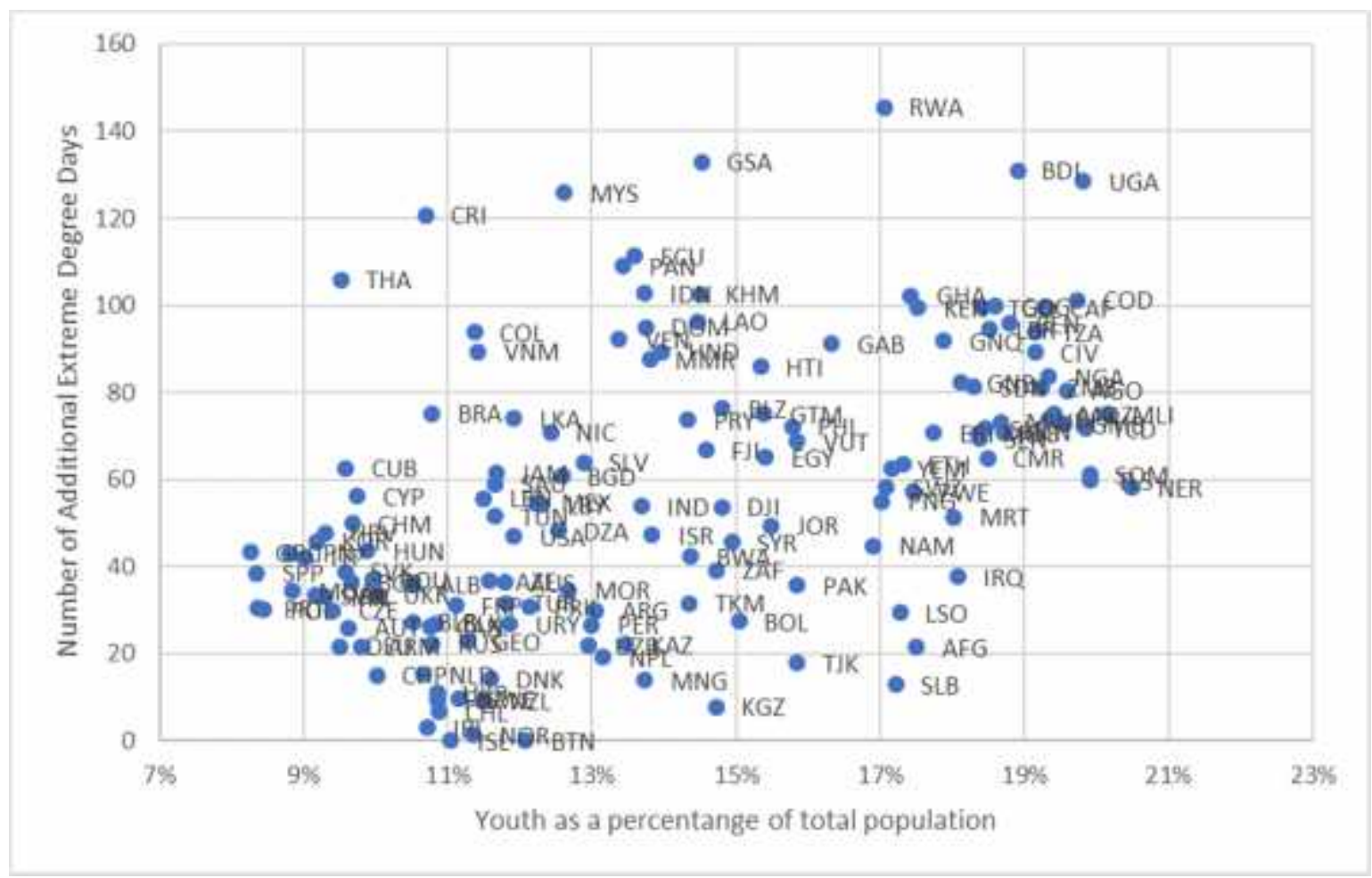

Note: The y axis shows the number of additional extreme heat days in 2050 relative to historical averages. For example, Uganda (UGA) has 55.6 extremely hot days under the historical climate, while in a 2050-like climate (HadGEM2/2055/RCP 8.5), the number of extreme heat days is 184.2. Countries such as Somalia (SOM) experience fewer additional extreme heat days, since historically they already have a high number of such days.

Source: Authors, based on data from Riahi et al. (2017) and Robertson (2016). 
Figure 5. Agriculture share of GDP in 2016 vs. youth as a percentage of the population (2030)

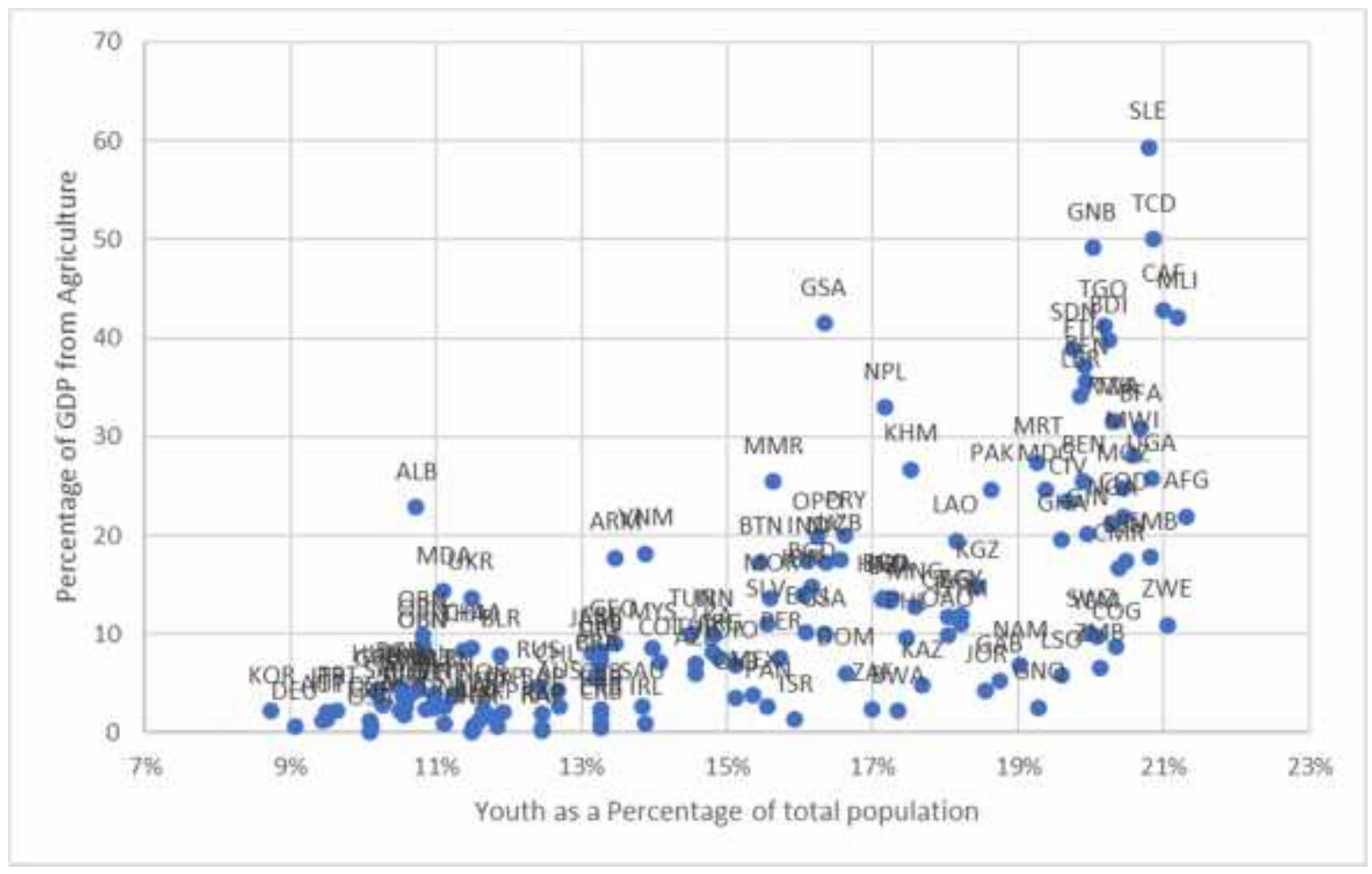

Source: Authors, based on data from Riahi et al. (2017) and Rosegrant et al. (2017). 
Figure 6. Change in agricultural revenue due to climate change vs. youth as a percentage of the population (2030)

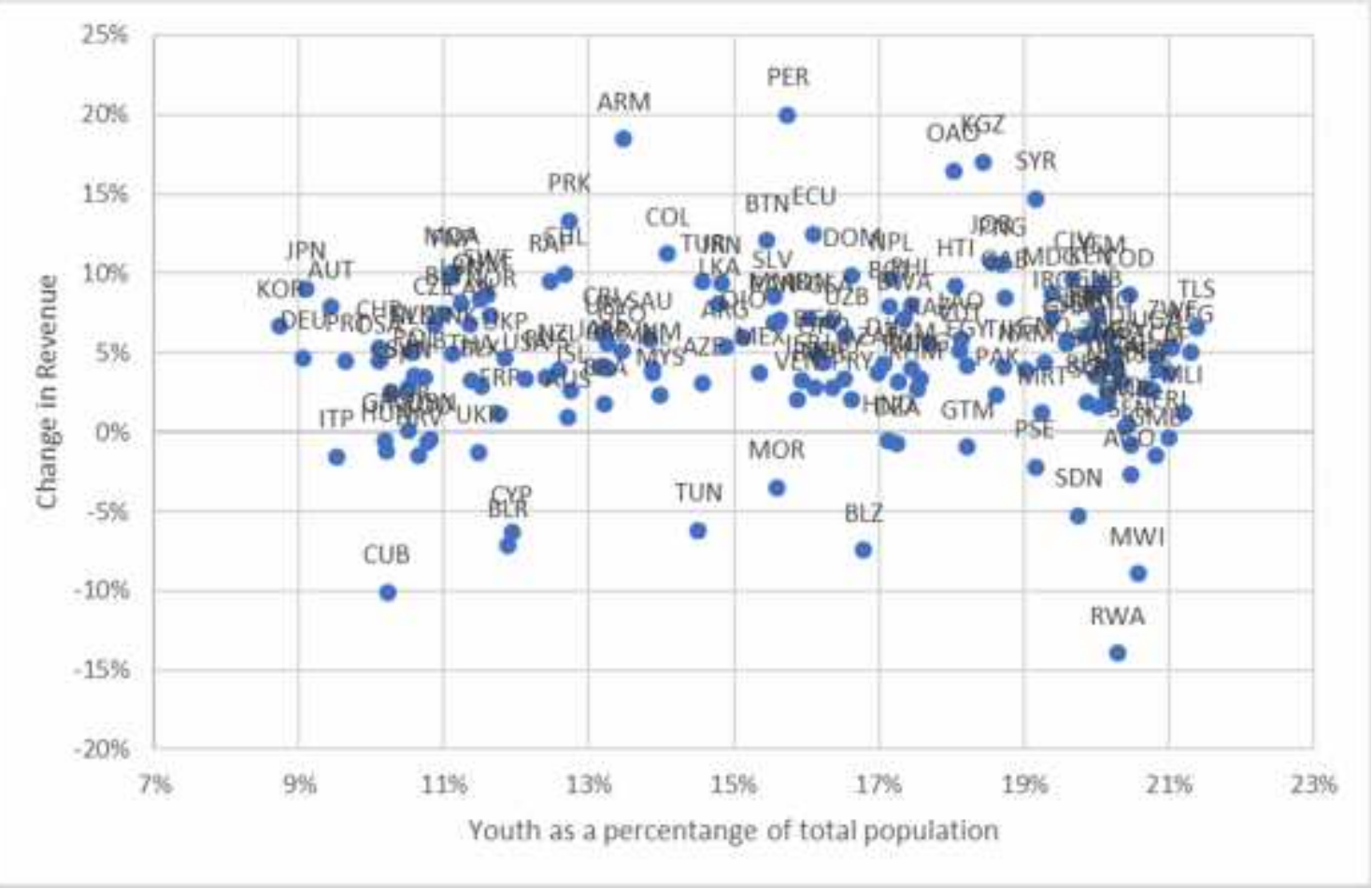

Source: Authors, based on data from Riahi et al. (2017) and Rosegrant et al. (2017).

Figure 7. Change in revenue due to climate change vs. youth as a percentage of the population (2050)

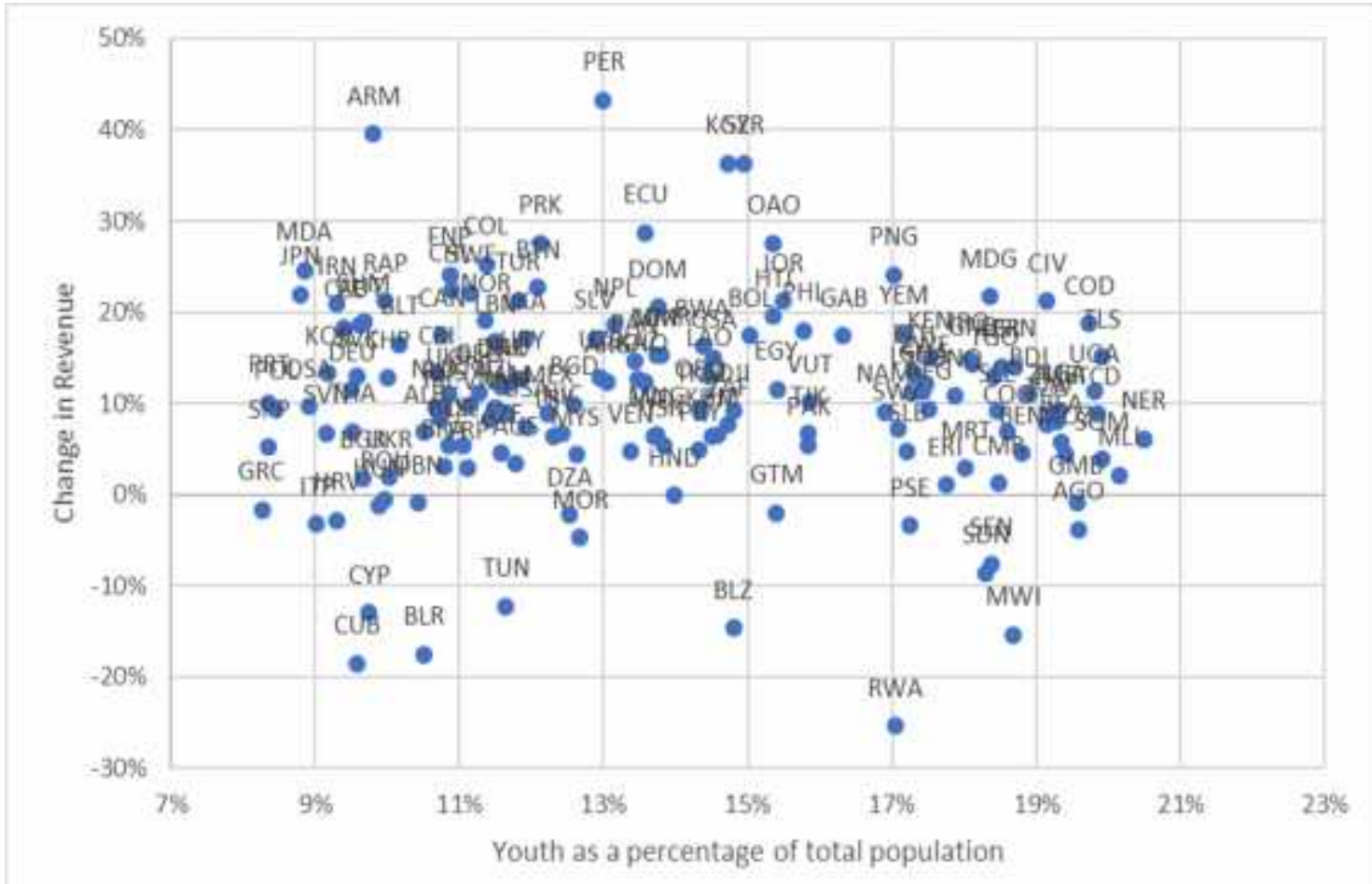

Source: Authors, based on data from Riahi et al. (2017) and Rosegrant et al. (2017). 
Figure 8. Impact of climate change and promising technologies on yields of selected crops

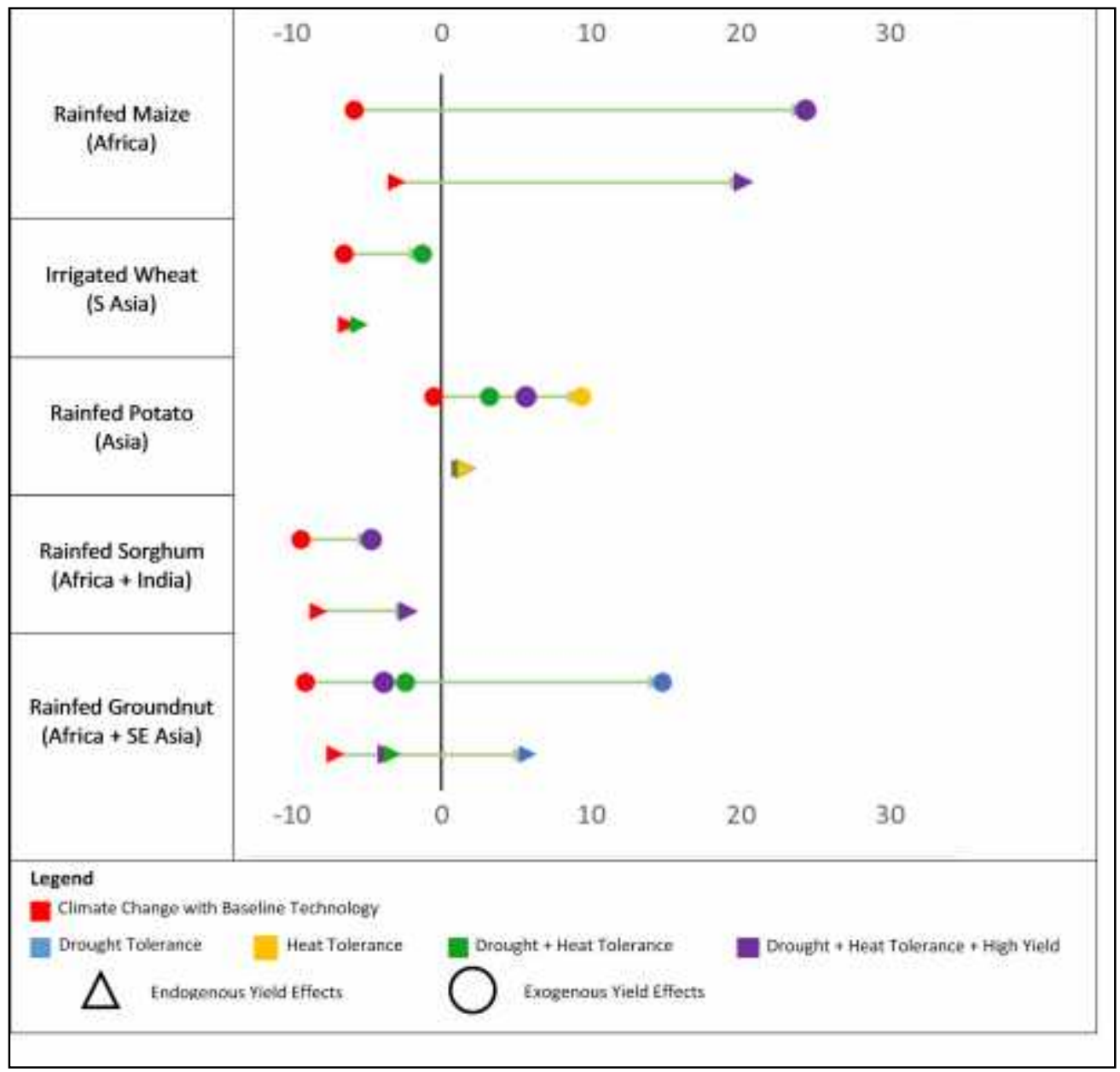

Source: Islam et al. (2016). 
Figure 9. Unemployment rate in South Africa by age cohort (2018 data for the first quarter only)

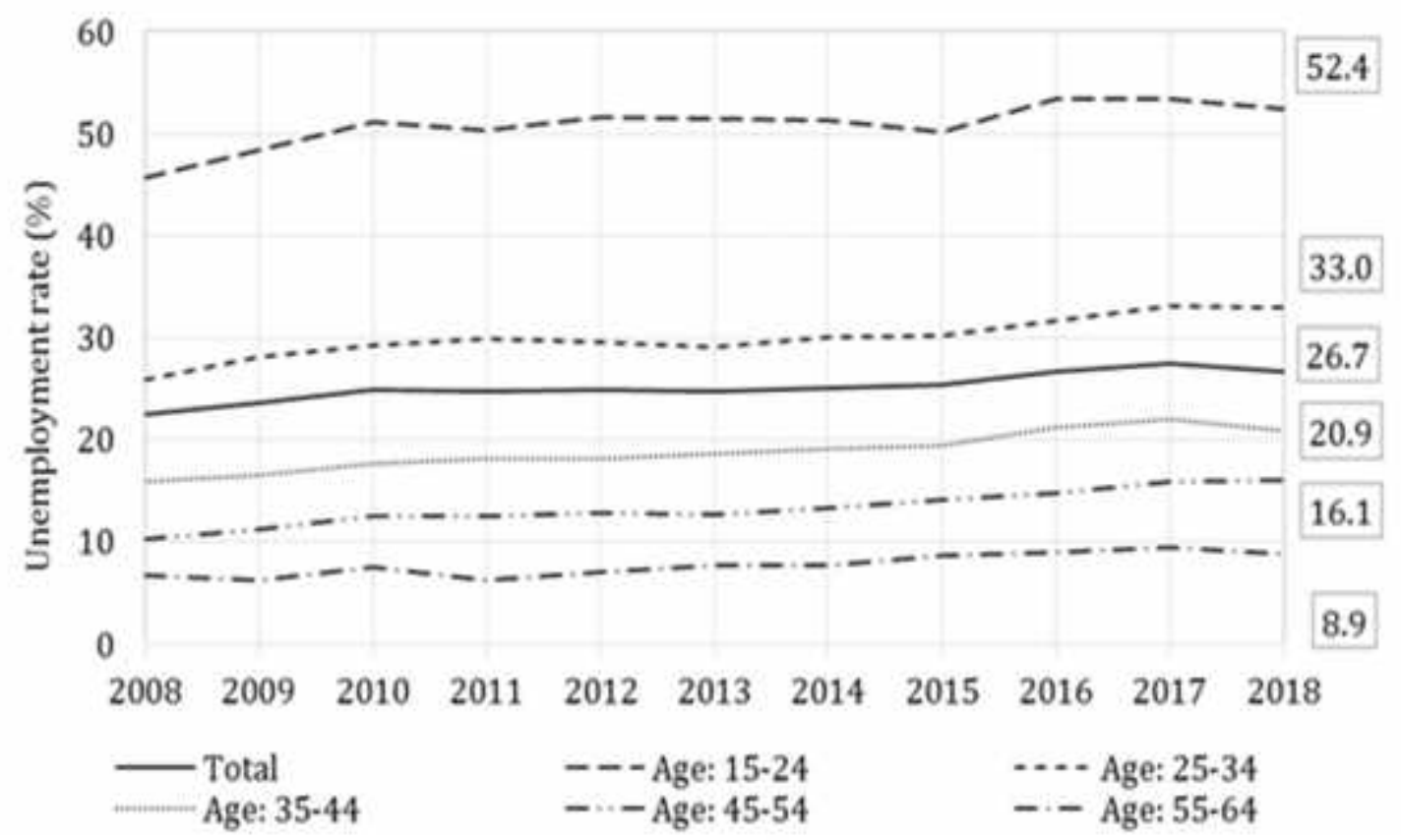

Source: Authors, based on data from Statistics South Africa (2018).

Figure 10. Educational attainment in Africa south of the Sahara by age cohort and occupation

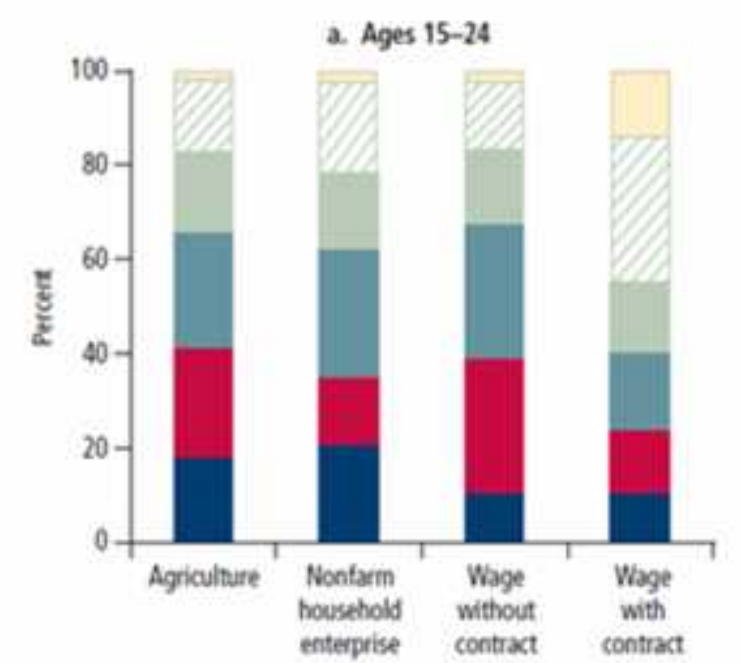

no education

Iir Lower secondary completed

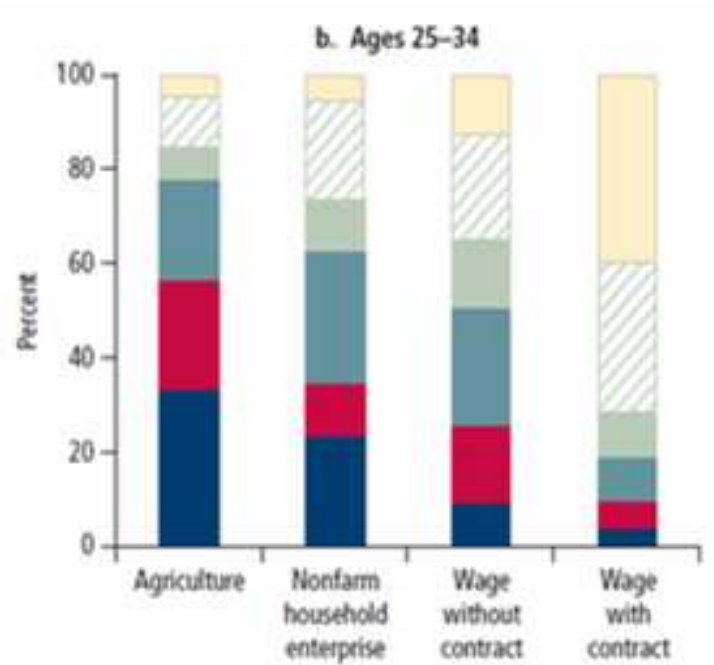

Primary not completed Upper secondary completed
Primary completed

Post-secondary

Source: Filmer and Fox (2014). 
Figure 11. Investment in agricultural science in 2013 as a proportion of agricultural GDP and projected youth as proportion of population in 2030

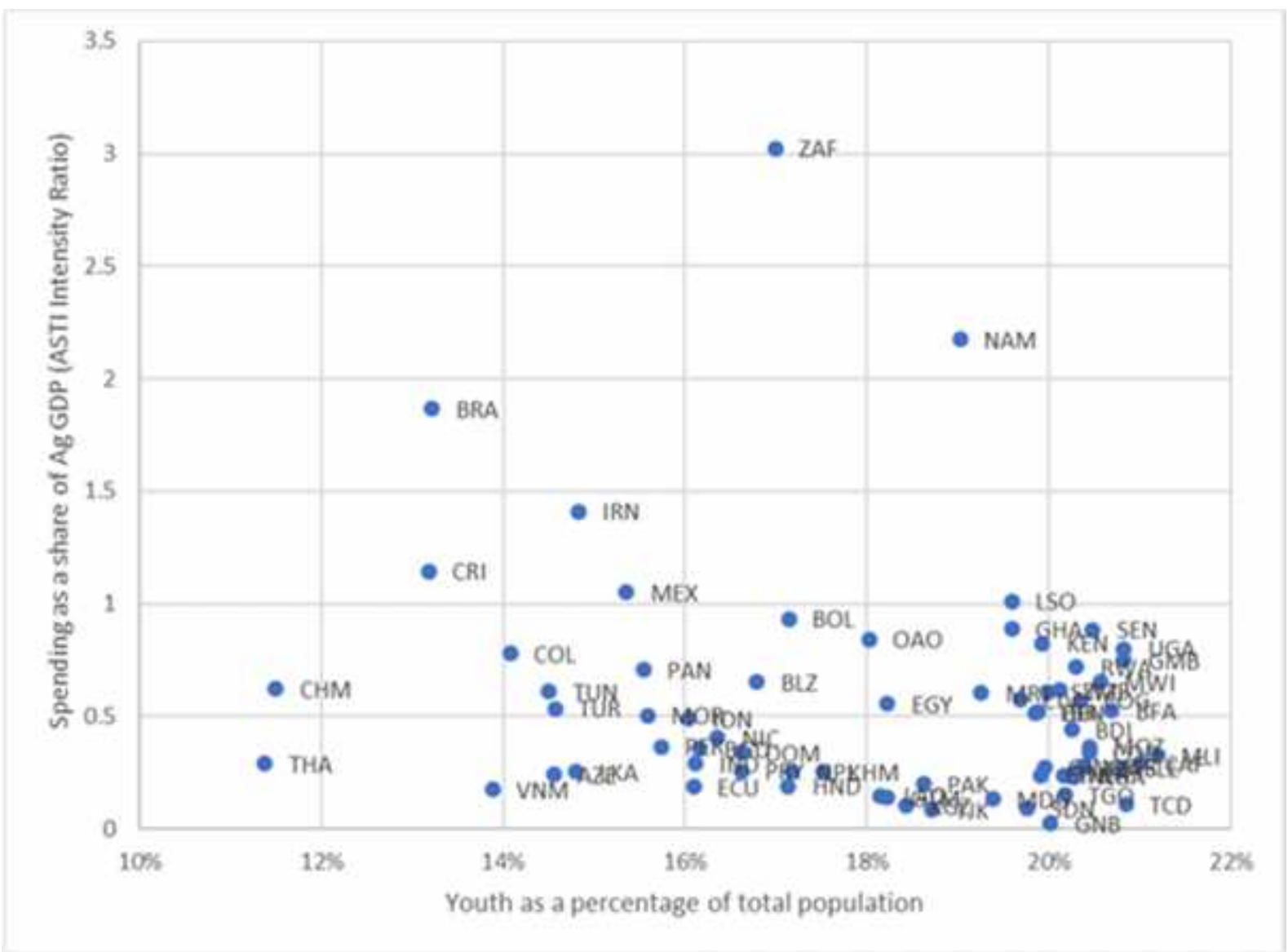

Source: Authors, based on data from Rosegrant et al. (2017) and ASTI (2018) 


\section{References}

Ahsan, R. N. and Mitra, D. (2016). Can the Whole be Greater than the Sum of Its Parts? Lessons from India's Growing Economy and its Evolving Structure. In M. McMillan, D. Rodrik and C. Sepulveda (Eds.), Structural Change, Fundamentals, and Growth: A Framework and Case Studies (pp. 3846). Washington, D.C.: International Food Policy Research Institute. https://dx.doi.org/10.2499/9780896292147

Arndt, C. and Thurlow, J. (2015). Climate Uncertainty and Economic Development: Evaluating the Case of Mozambique to 2050. Climatic Change, 130, 63-75. https://doi.org/10.1007/s10584-0141294-x

ASTI (2018). Agricultural Science and Technology Indicators. Retrieved February 4, 2018, from https://www.asti.cgiar.org

Brooks, K. (2018). Rising Absolutely, Declining Relatively: Agriculture, Climate Change, and Job Creation in Africa. Agrekon, 57(3-4), 181-197. https://doi.org/10.1080/03031853.2018.1538002

Cullis, J., Alton, T., Arndt, C., Cartwright, A., Chang, A., Gabriel, S., Thurlow, J. (2015). An Uncertainty Approach to Modelling Climate Change Risk in South Africa, WIDER Working Paper 2015/045. Helsinki: UNU-WIDER

De Pinto, A., Kwon, H. Y., Cenacchi, N. and Dunston, S. (2017). The Effects of Widespread Adoption of Climate-smart Agriculture in Africa South of the Sahara Under Changing Climate Regimes. ReSAKSS Annual Trends and Outlook Report. https://doi.org/10.2499/9780896292949_03

Diao, X., McMillan, M. and Rodrik, D. (2017). The Recent Growth Boom in Developing Economies: A Structural Change Perspective. NBER Working Paper Series. Cambridge, MA: National Bureau of Economic Research. https://doi.org/10.3386/w23132

FAO (2018). Food Price Index. Rome Italy: Food and Agriculture Organization of the United Nations. Retrieved February 4, 2018, from http://www.fao.org/worldfoodsituation/foodpricesindex/en/

Filmer, D., and Fox, L. 2014. Youth Employment in Sub-Saharan Africa. Washington, DC: World Bank. https://doi.org/10.1596/978-1-4648-0107-5

General Statistics Office. (2015). Statistical Yearbook of Vietnam. Retrieved from http://www.mpi.gov.vn/en/Pages/tinbai.aspx?idTin=36871\&idcm=109

General Statistics Office. (2017). Report on Labour Force Survey. Retrieved from https://www.gso.gov.vn/default_en.aspx?tabid=515\&idmid=5\&ltemID=18833

Guldberg, O. H.-, Jacob, D., Taylor, M., Bindi, M., Brown, S., Camilloni, I., ... Zougmore, R. (2018). Chapter 3: Impacts of 1.5C Global Warming on Natural and Human Systems. In Global Warming of $1.5^{\circ} \mathrm{C}$ : An IPCC Special Report on the Impacts of Global Warming of $1.5^{\circ} \mathrm{C}$ Above Pre-industrial Levels and Related Global Greenhouse Gas Emission Pathways, in the Context of Strengthening the Global Response to the Threat of Climate Change. Intergovernmental Panel on Climate Change. http://pure.iiasa.ac.at/id/eprint/15518/

Hoogenboom, G., Porter, C. H., Shelia, V., Boote, K. J., Singh, U., White, J. W., ... Jones, J. W. (2012). Decision Support System for Agrotechnology Transfer (DSSAT) Version 4.5. Honolulu, HI: University of Hawaii. https://dssat.net 
IFAD (2016). Rural Development Report 2016. Rome, Italy: International Fund for Agricultural Development. https://doi.org/10.1016/j.ijplas.2013.08.003

Islam, S., Cenacchi, N., Sulser, T. B., Gbegbelegbe, S., Hareau, G., Kleinwechter, U., ... Wiebe, K. (2016). Structural Approaches to Modeling the Impact of Climate Change and Adaptation Technologies on Crop Yields and Food Security. Global Food Security, 10, 63-70. https://doi.org/10.1016/j.gfs.2016.08.003

Jones, J. W., Hoogenboom, G., Porter, C. H., Boote, K. J., Batchelor, W. D., Hunt, L. A., ... Ritchie, J. T. (2003). The DSSAT Cropping System Model. European Journal of Agronomy, 18(3), 235-265. https://doi.org/10.1016/S1161-0301(02)00107-7

KPMG and FICCI (2015). Labour in Indian Agriculture: A Growing Challenge. Retrieved from http://ficci.in/publication.asp?spid=20550

McMillan, M., Rodrik, D. and Sepulveda, C. (2017). Structural Change, Fundamentals and Growth: A Framework and Case Studies: Synopsis. Washington, D.C.: International Food Policy Research Institue (IFPRI). http://dx.doi.org/10.2499/9780896292147

Murtin, F. (2013). Improving Education Quality in South Africa. OECD Economics Department Working Paper. Paris, France: Organisation for Economic Co-operation and Development. https://doi.org/10.1787/5k452klfn9ls-en

Nin-Pratt, A. (2016). Comparing Apples to Apples: A New Indicator of Research and Development Investment Intensity in Agriculture. IFPRI Discussion Paper 1559. Washington, D.C.: International Food Policy Research Institute. http://ebrary.ifpri.org/cdm/ref/collection/p15738coll2/id/130713

Riahi, K., van Vuuren, D. P., Kriegler, E., Edmonds, J., O'Neill, B. C., Fujimori, S., ... Tavoni, M. (2017). The Shared Socioeconomic Pathways and Their Energy, Land Use, and Greenhouse Gas Emissions Implications: An Overview. Global Environmental Change, 42, 153-168. https://doi.org/10.1016/j.gloenvcha.2016.05.009

Ricker-Gilbert, J. and Chamberlin, J. (2018). Transaction Costs, Land Rental Markets, and Their Impact on Youth Access to Agriculture in Tanzania. Land Economics, 94, 541-555. https://doi.org/10.3368/le.94.4.541

Robertson, R. (2016). Heat Strees Could be a Problem or Livestock Living Outdoors under Climate Change. IFPRI Climate Change. Washington, D.C.: International Food Policy Research Institute. $\mathrm{http}: / /$ climatechange.ifpri.info/heat-stress-could-be-a-problem-for-livestock-living-outdoors-underclimate-change/

Robinson, S., Mason-D'Croz, D., Islam, S., Sulser, T. B., Robertson, R. D., Zhu, T. ... Rosegrant, M. W. (2015a). The International Model for Policy Analysis of Agricultural Commodities and Trade (IMPACT): Model Description for Version 3. IFPRI Discussion Paper 1483. Washington, D.C.: International Food Policy Research Institute. http://ebrary.ifpri.org/cdm/ref/collection/p15738coll2/id/129825

Robinson, S., Mason-D'Croz, D., Islam, S., Cenacchi, N., Creamer, B., Gueneau, A., ... Wiebe, K. (2015b). Climate Change Adaptation in Agriculture: Ex Ante Analysis of Promising and Alternative Crop Technologies using DSSAT and IMPACT. IFPRI Discussion Paper 1469. Washington, D.C.: International Food Policy Research Institute. https://hdl.handle.net/10568/72508

Rosegrant, M. W., Sulser, T., Mason-D'Croz, D., Cenacchi, N., Pratt, A., Islam, S., ... Willaarts, B. (2017). Quantitative Foresight Modeling to Inform the CGIAR Research Portfolio. Washington, 
D.C.: International Food Policy Research Institute.

http://ebrary.ifpri.org/cdm/ref/collection/p15738coll2/id/131144

Statistics South Africa (2018). Quarterly Labour Force Survey 2008-2018. Pretoria: South Africa, Government of South Africa. Retrieved March 8, 2018, from http://www.statssa.gov.za/?page_id=1866\&PPN=P0211\&SCH=7331

Swinnen, J. and Squicciarini, P. (2012). Mixed Messages on Prices and Food Security. Science, 335(6067), 405-406. https://doi.org/10.1126/science.1210806

Thurlow, J., Randriamamonjy, J. and Benson, T. (2018). Identifying Priority Value Chains in Tanzania. Research Paper No. 106. East Lansing, Ml: Feed the Future Innovation Lab for Food Security Policy. http://ebrary.ifpri.org/cdm/ref/collection/p15738coll2/id/132795

UNDESA (United Nations Department of Economic and Social Affairs), Population Division. 2017. World Population Prospects. New York: United Nations (available at: https://population.un.org/wpp/Download/Standard/Population/)

UNU-WIDER (2012). Implications of Climate Change for Economic Growth and Development in Vietnam to 2050 [in Vietnamese]. Helsinki, Finland: United Nations University World Institute for Development Economics Research.

Uys, D. W. and Alant, E. J. T. (2015). Estimation of Promotion, Repetition and Dropout Rates for Learners in South African Schools, Perspectives in Education, 33 (3), 20-41.

Wiebe, K., Stads, G. J., Beintema, N., Brooks, K., Cenacchi, N., Dunston, S., ... Thomas, T. (2017). West African Agriculture for Jobs, Nutrition, Growth, and Climate Resilience. IFPRI Discussion Paper. Washington, D.C.: International Food Policy Research Institute. http://ebrary.ifpri.org/utils/getfile/collection/p15738coll2/id/131462/filename/131672.pdf

World Bank. (2017). World Development Indicators. Retrieved March 8, 2018, from https://datacatalog.worldbank.org/dataset/world-development-indicators

Yeboah, F. K. and Jayne, T. S. (2018). Africa's Evolving Employment Trends. The Journal of Development Studies, 54(5), 803-832. https://doi.org/10.1080/00220388.2018.1430767. 
- The demography of rural youth in developing countries By Guy Stecklov, Ashira Menashe-Oren

- What drives rural youth welfare? The role of spatial, economic, and household factors By Aslihan Arslan, David Tschirley, Eva-Maria Egger

- Youth agrifood system employment in developing countries: a gender-differentiated spatial approach

By Michael Dolislager, Thomas Reardon, Aslihan Arslan, Louise Fox, Saweda Liverpool-Tasie, Christine Sauer, David Tschirley

- Gender, rural youth and structural transformation: Evidence to inform innovative youth programming

By Cheryl Doss, Jessica Heckert, Emily Myers, Audrey Pereira, Agnes Quisumbing

- Rural outh inclusion, empowerment and participation

By Carolina Trivelli, Jorge Morel

- Economic participation of rural youth: what matters?

By Louise Fox

- Landscapes of rural youth opportunity

By James Sumberg, Jordan Chamberlin, Justin Flynn, Dominic Glover and Vicky Johnson

- Rural youth, today and tomorrow

By Ben White

- Climate and jobs for rural young people

By Karen Brooks, Shahnila Dunston, Keith Wiebe, Channing Arndt, Faaiqa Hartley and Richard Robertson

- Rural transformation and the double burden of malnutrition among rural youth in developing countries

By Suneetha Kadiyala, Elisabetta Aurino, Cristina Cirillo, Chittur S. Srinivasan and Giacomo Zanello

- Inclusive finance and rural youth

By Arianna Gasparri, Laura Munoz

- Information and communication technologies and rural youth By Jenny Aker

- Youth access to land, migration and employment opportunities: evidence from sub-Saharan Africa

By Felix Kwame Yeboah, Thomas S. Jayne, Milu Muyanga and Jordan Chamberlin

- Rural youth in the context of fragility and conflict

By Ghassan Baliki, Tilman Brück (Team Leader), Neil T. N. Ferguson and Wolfgang Stojetz

- Rural youth: determinants of migration throughout the world By Alan de Brauw

- The Impact of Migrants' Remittances and Investment on Rural Youth By Manuel Orozco, Mariellen Jewers

- Unlocking the potential of rural youth: the role of policies and institutions By Lauren Phillips, Paola Pereznieto

- Investing in rural youth in the Asia and the Pacific region By Roehlano Briones 
- The rural youth situation in Latin America and the Caribbean By Maia Guiskin, Pablo Yanes, Miguel del Castillo Negrete

- Investing in rural youth in the Near East, North Africa, Europe and Central Asia By Nader Kabbani

- The narrative on rural youth and economic opportunities in Africa: Facts, myths and gaps By Athur Mabiso, Rui Benfica

All publications in the IFAD Research Series can be found at:

https://www.ifad.org/en/web/knowledge/series?mode=search\&catSeries=39130673 



\section{JUIFAD}

International Fund for Agricultural Development Via Paolo di Dono, 44 - 00142 Rome, Italy

Tel: +390654591 - Fax: +39065043463

Email: ifad@ifad.org

www.ifad.org

f facebook.com/ifad

(2) instagram.com/ifadnews

in linkedin.com/company/ifad

twitter.com/ifad

youtube.com/user/ifadTV
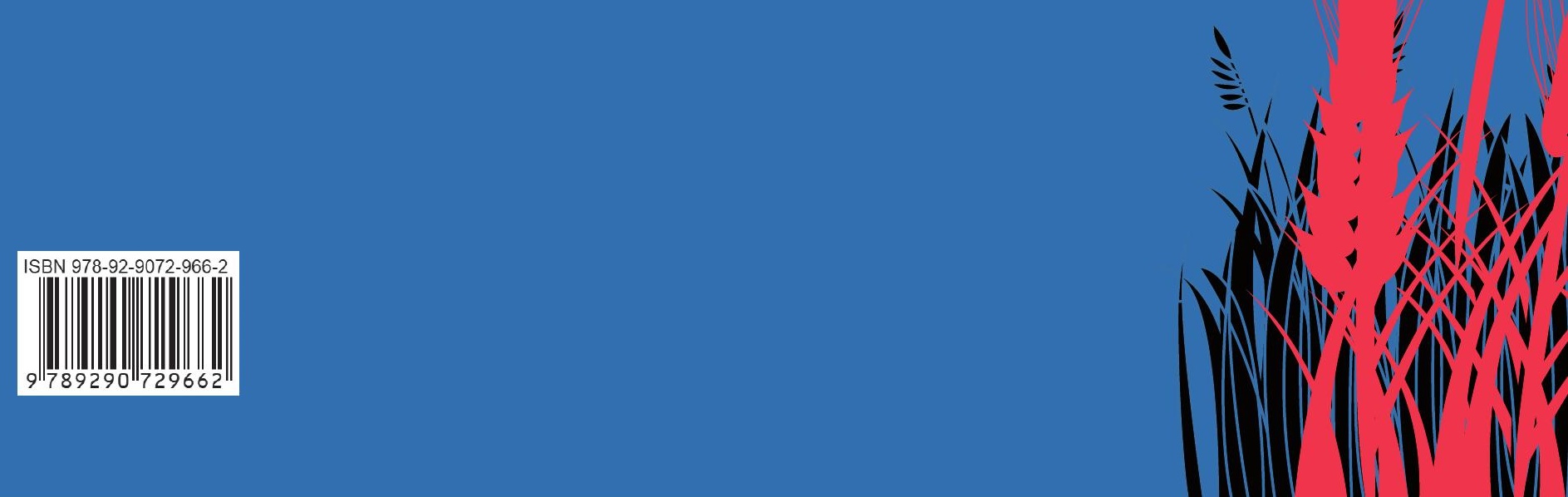